\title{
Article \\ Optimal Sizing and Techno-Economic Analysis of Minigrid Hybrid Renewable Energy System for Tourist Destination Islands of Lake Tana, Ethiopia
}

\author{
Teketay Mulu Beza (D), Chen-Han Wu and Cheng-Chien Kuo *D
}

check for updates

Citation: Beza, T.M.; Wu, C.-H.; Kuo, C.-C. Optimal Sizing and Techno-Economic Analysis of Minigrid Hybrid Renewable Energy System for Tourist Destination Islands of Lake Tana, Ethiopia. Appl. Sci. 2021, 11, 7085. https://doi.org/ 10.3390/app11157085

Academic Editor: Luis

Hernández-Callejo

Received: 25 June 2021

Accepted: 28 July 2021

Published: 31 July 2021

Publisher's Note: MDPI stays neutral with regard to jurisdictional claims in published maps and institutional affiliations.

Copyright: (c) 2021 by the authors. Licensee MDPI, Basel, Switzerland. This article is an open access article distributed under the terms and conditions of the Creative Commons Attribution (CC BY) license (https:// creativecommons.org/licenses/by/ $4.0 /)$.
Department of Electrical Engineering, National Taiwan University of Science and Technology, 43, Sec. 4, Keelung Rd., Taipei 10607, Taiwan; teketay.mulu@bdu.edu.et (T.M.B.); d10907002@mail.ntust.edu.tw (C.-H.W.)

* Correspondence: cckuo@mail.ntust.edu.tw; Tel.: +886-9-2088-1490; Fax: +886-2-2737-6688

\begin{abstract}
Achieving universal electricity access is a challenging goal for the governments of developing countries such as Ethiopia. Extending the national grid to the remotely located, scattered, and island populations demands a huge investment. This paper aims to show the techno-economic feasibility of minigrid renewable energy system to electrify Kibran Gabriel island in Ethiopia, through the execution of simulation, optimization and sensitivity analysis using Hybrid Optimization Models for Energy Resources (HOMER Pro) software. The minigrid systems were compared with both diesel generation (DG) and grid extension systems. The hybrid photovoltaic (PV)/DG/battery system is more economically feasible compared with other minigrid systems, and the best cost-effective option is the one including load flow (LF) strategy with $25 \mathrm{~kW}$ of PV, $10 \mathrm{~kW}$ of DG, $40 \mathrm{kWh}$ of battery, and $5 \mathrm{~kW}$ of bi-directional convertor. The optimal PV/DG/Battery system, having levelized cost of energy (COE) of USD 0.175/kWh, net present cost (NPC) of USD 119,139 and renewable fraction (RF) of $86.4 \%$, reduces the pollutant emissions by $33,102 \mathrm{~kg} / \mathrm{yr}$ compared with the stand-alone DG system. The optimal minigrid sensitivity to the variations in global horizontal irradiance (GHI), diesel price and load consumption were considered in the sensitivity analysis, and the result shows that the system will operate reasonably well.
\end{abstract}

Keywords: hybrid renewable energy; minigrid; rural electrification; optimal sizing; techno-economic analysis; grid-extension cost; sensitivity analysis

\section{Introduction}

Energy poverty is a serious problem that must be addressed for the sustainable development of a community. Of different forms of energy, electrical energy is the one that has become part and parcel of our lives. Nowadays, electricity access is closely linked to aspects of human development such as healthcare, sanitation, educational access, and employment rate [1]. That is why it is given priority attention in the sustainable development goals (SDGs) — specifically, as stated in SDG-7: access to affordable, reliable, sustainable and modern energy for all [2]. According to the International Energy Agency (IEA), the number of people in sub-Saharan Africa without access to electricity was estimated to be 580 million in 2019, while the number of people without access to clean cooking facilities was estimated to be about 900 million [3]. Similar studies showed that a number of people without access to electricity reside in rural areas of sub-Saharan Africa and South Asia [4].

The rural off-grid communities rely heavily on conventional energy resources such as firewood, animal dung, kerosene, petroleum, and candles. However, these resources have negative consequences on the environment as well for human health [5].

The main challenge today is to supply electricity to people who are not yet connected to the grid in sub-Saharan African countries, such as Ethiopia. There are four possible solutions to alleviate the problem: (1) grid extension; (2) standalone diesel based power generation (DG); (3) solar home systems (SHS); and (4) islanded minigrid systems (MGS). 
Grid extension is relatively reliable in power quality but it is a very expensive alternative for delivering electricity access to remotely located, scattered and island populations. The DG system is the other option for electricity access for rural off-grid communities. However, diesel fuel transportation, pollutant emissions during power generation, high operating costs, and harmful effects on human health and the environment have made this option unfavorable [4]. SHS is the third option which has been used in rural off-grid communities. It is a portable and low-cost system with limited electrification capabilities to support large loads [6]. SHS basically delivers electricity for lighting and charging. However, the economic value SHS injects into the community is very limited due to the capacity of power delivery [7]. Compared to the first three technologies, MGS have been deemed a better choice because of their potential to enable electrification beyond subsistence level living. In addition, the hybrid minigrid systems are considered a cost-effective alternative for the rural off-grid communities [8].

In the sector of renewable energies, the increase in electrical energy generated by wind and solar was relatively the fastest. For example, the global solar PV installed capacity rosed from less than $1 \mathrm{GW}$ in 2000 to $227 \mathrm{GW}$ in 2015 [9,10]. Similarly, the globally installed capacity of wind power increased from 59 GW in 2005 to $433 \mathrm{GW}$ in 2015 [9]. However, optimal sizing and techno-economic analysis of hybrid minigrid systems for rural communities have been the main issue for many scholars. The related literature is discussed below.

Emad et al. [11] made a review of the computational methods for the planning of hybrid renewable microgrids. The paper addressed the uncertainties in solar and wind energy resources and gives good insights for future researchers in this regard. Suman et al. [12] conducted a study to optimize an off-grid PV/wind/biogenerator system integrated with diesel and a storage system using hybrid particle swarm optimization and a grey wolf optimizer. Ko et al. [13] proposed an energy storage system model combined with PV system to explore the impact of incentives on power plant operations. Similarly, a hybrid energy management system for islanded networked microgrids considering battery energy storage and wasted energy was discussed in [14]. Bahramara et al. [15] presented a review of optimal planning tools considering investment and operation costs, meeting technical and emission constraints, and optimal sizing renewables. On the other hand, Rana et al. [16] proposed a novel peak load shaving algorithm for an isolated PV/battery microgrid system. However, excess energy, peak load handling, initial capital cost and optimal sizing are still controversial in PV/battery systems. The optimal sizing of an off-line microgrid system using multiobjective simulated annealing particle swarm optimizer was proposed in [17]. However, the study mainly considers batteries and diesel generators to increase system reliability.

Oladigbolu et al. [18] carried out a comparative analysis of hybrid renewable power system for off-grid rural electrification in Nigeria. According to the analysis a hybrid hydro/PV/wind/diesel/battery system with $77.4 \%$ renewable fraction was proposed for that specific site. Odou et al. [19] tried to optimize a hybrid off-grid renewable power system for rural communities in Benin, and the PV/diesel/battery system was the least costly system identified in the analysis. The study also indicated a $70 \%$ battery size reduction compared to PV/battery system. A co-optimization scheme using the Lagrange multiplier method for distributed energy resource planning in community microgrids was carried out in [20]. The study optimized the total annualized cost at the maximum fuel saving. Gebrehiwot et al. [21] proposed an off-grid hybrid power system for the village named Golbo II, in Ethiopia. According to this study, the PV/wind/diesel/battery system with a cost of energy of USD $0.207 / \mathrm{kWh}$ was the optimal solution. Similar studies taking into consideration the load demand and the environmental conditions of specific sites have been conducted in [12,22-24]. 
In accordance with worldwide trends, the Government of Ethiopia has set key targets for its energy sector, with the goal of providing electric power to all citizens by the end of 2030 [25]. The government has a vision to provide high quality energy services to all sectors of the economy, as well as to export power to neighboring countries via the East African Power Pool [26]. Renewable energy sources such as hydropower, photovoltaics, wind, and geothermal energy have been identified as promising possibilities for Ethiopia's energy security and environmental management in order to mitigate the harmful consequences of climate change [26,27]. However, rural electrification in the remote areas and small islands of Ethiopia through grid extension demands a huge capital investment because of the dispersed population, and difficult geographic terrain. According to the IEA, African energy outlook 2019 special report, Ethiopia has an electricity access rate of only $45 \%$; nearly 60 million people do not have access to electricity [28]. Only $11 \%$ of the population has access to electricity through decentralized solutions, mainly from stand-alone diesel and PV.

Considering the research gaps and the real problem on the ground at the specified site, the authors proposed optimal sizing and techno-economic analysis of the minigrid hybrid renewable energy system in comparison with grid-extension and diesel power generation for Kibran Gabriel island of Ethiopia. In addition to the optimal minigrid system, e.g., other alternative configurations, the pollutant emission gases that can be reduced, the optimal system sensitivity to the variations of GHI, load consumption and diesel price are addressed in the analysis.

The remainder of this paper is organized as follows: Section 2 describes materials and methods, whereas in Section 3 resources and demand of the case study are presented. Minigrid hybrid system discerptions, and component cost and financial assumptions are discussed in Sections 4 and 5, respectively. The simulation results and discussion are provided in Section 6, then a brief conclusion follows in Section 7.

\section{Materials and Methods}

This study mainly aims to show the techno-economic viability of the minigrid system for Kibran Gabriel island. Using HOMER Pro software, the feasible configurations and system sizing for the optimal system were carried out. The required data for simulation analysis were acquired from multiple sources: the weather data of the island was obtained from NASA surface meteorology and solar energy database integrated in HOMER Pro [29]. In addition, the load data, diesel fuel price, interest rate and inflation rate, grid extension cost, and e-market surveys for equipment costs were required for the analysis.

- The load profile of the island was estimated and categorized into primary loads (power is required at a specific time) and deferrable loads (power is required but time is flexible).

- Since the island is not fully electrified yet, in the simulation analysis, electrifying the island with diesel generator was considered as a reference for other comparisons. Despite the pollution, the economic feasibility of diesel power generation relative to grid-extension cost was also considered for further comparisons.

- We considered different feasible configurations of PV/wind/battery, PV/wind/diesel/ battery, PV/battery, and PV/diesel/battery systems compared with the stand-alone DG system, and finally the optimal system was determined.

- Once the optimal system was determined, sensitivity analysis was carried out to observe the effects of the variation of important parameters such as global horizontal irradiation, diesel fuel price, and load consumption on the optimal system.

- Finally, the optimal size and techno-economically feasible configuration were determined. The minimum LCOE, and NPC, the total emissions reduced (compared with stand-alone diesel system), RF, capacity shortage fraction, and BGED and other parameters were computed. 


\section{Description of Simulation Software}

HOMER Pro software was developed by US National Renewable Energy Laboratory (NREL). The software is a powerful tool for designing, analyzing and planning of minigrid systems to determine the optimal size of system components through carrying out technoeconomic analysis [29]. Figure 1 depicts the HOMER Pro simulation process architecture diagram.

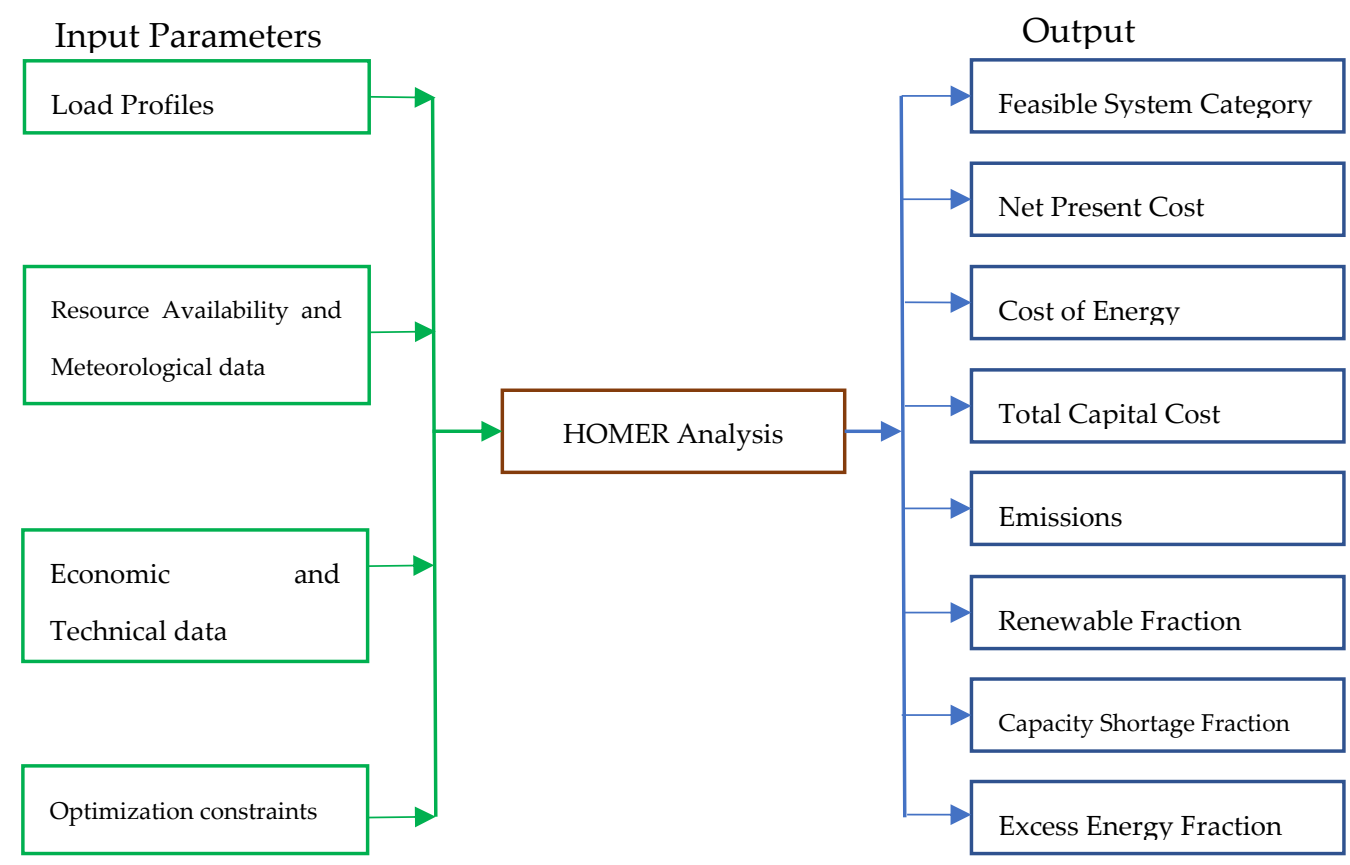

Figure 1. HOMER Pro analysis architecture diagram.

\section{Resources and Demand Assessment of the Case Study}

\subsection{Site Description}

Kibran Gabriel is one of Lake Tana islands located $11 \mathrm{~km}$ North West of Bahir Dar city, Ethiopia [30] with latitude $11.6516^{\circ}$ and longitude $37.3644^{\circ}$. Lake Tana is one of the UNESCO world biosphere reserve sites in Ethiopia, registered on 19 June 2015 [31]. It is the home of 37 islands, of which 20 have Ethiopian Orthodox churches and monasteries. Kibran Gabriel is endowed with historical and religious heritages that make it the most popular tourist destination among the Lake Tana islands. However, the communities living on the island do not have access to electricity. Negligible SHS and portable diesel generators are used during holidays. The major economic activities practiced are agriculture, fishery and sightseeing. The geographic location is indicated in Figure 2 below. 


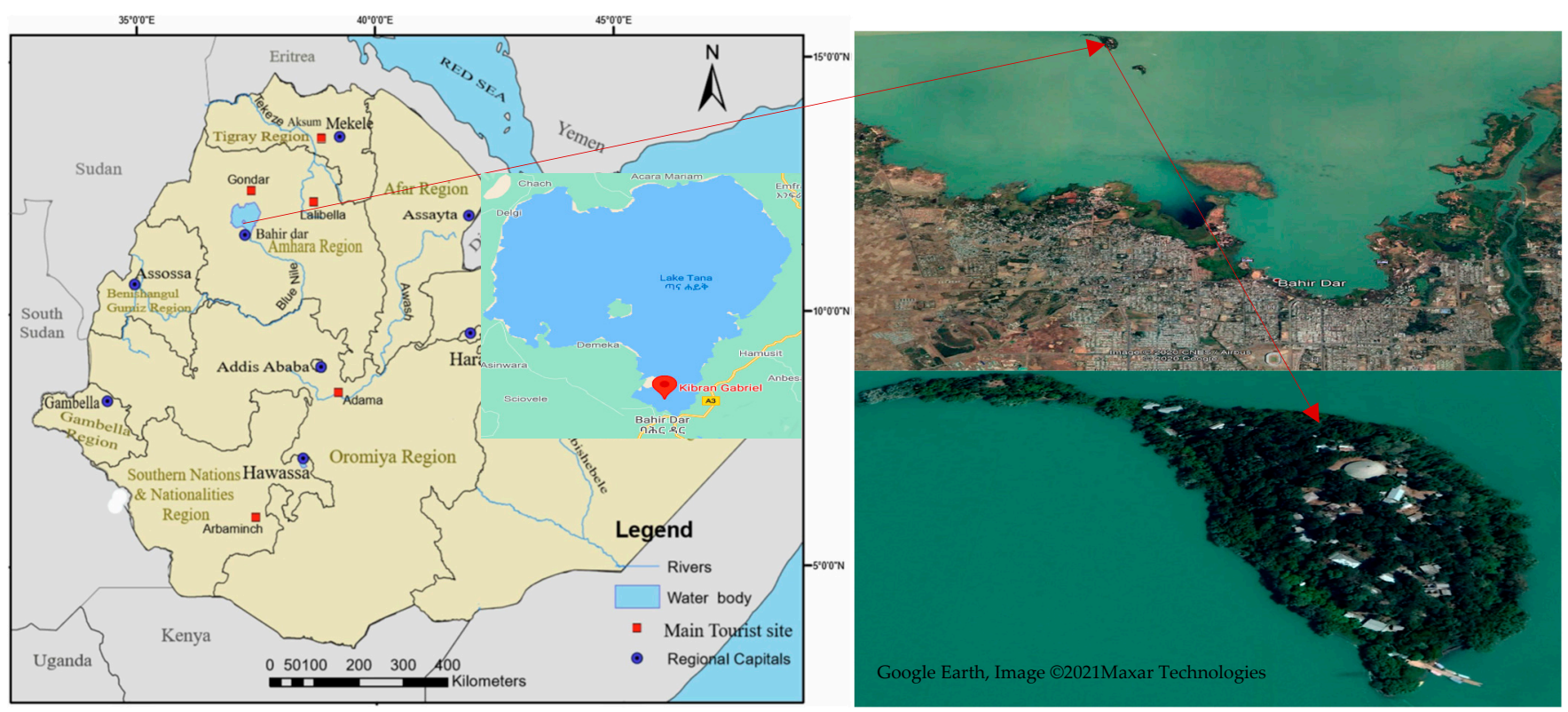

Figure 2. Geographic location of Kibran Gabriel island.

\subsection{Global Horizontal Irradiation and Wind Speed}

Providing the latitude and longitude of Kibran Gabriel island to HOMER Pro software, GHI and wind speed data of NASA can be found via Internet connection. According to the data obtained, daily average GHI is $5.94 \mathrm{kWh} / \mathrm{m}^{2} /$ day. As depicted in Figure 3, the daily average GHI for each month varies from the minimum $5.05 \mathrm{kWh} / \mathrm{m}^{2} /$ day in July to the maximum $6.68 \mathrm{kWh} / \mathrm{m}^{2} /$ day in April. The sky is relatively clearer in winter (November to May) than summer (June to October).

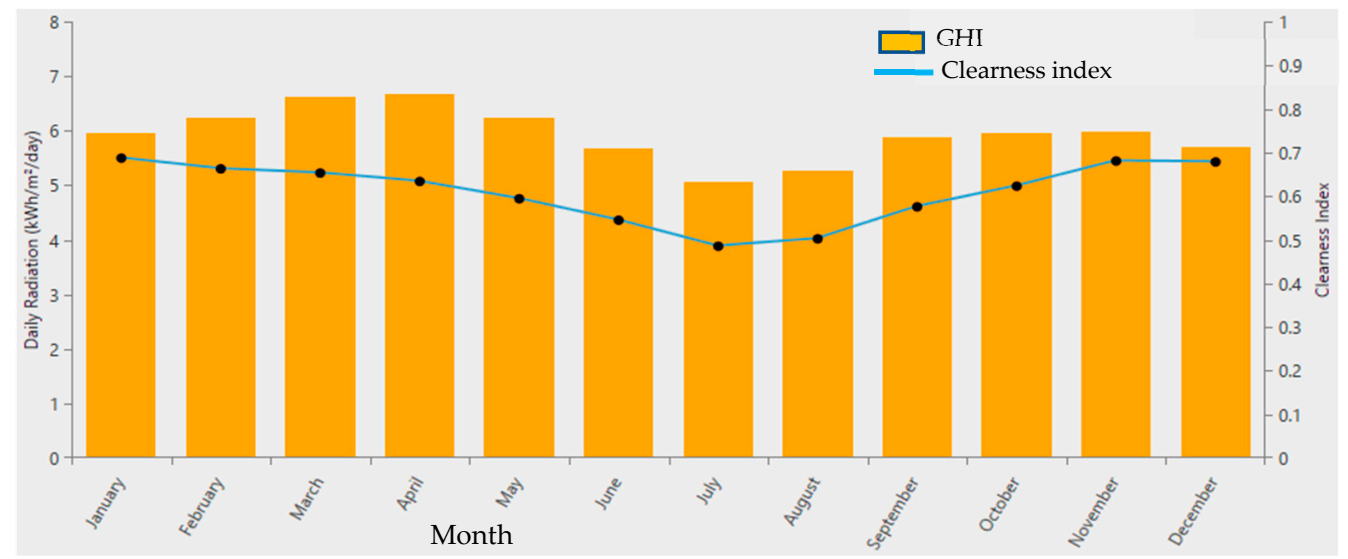

Figure 3. Average global horizontal irradiation data.

Similarly, the annual average wind speed data of the site taken from NASA. The annual average wind speed is $3.78 \mathrm{~m} / \mathrm{s}$ at $50 \mathrm{~m}$ above the surface of the earth. As shown in Figure 4, the relative minimum and the maximum monthly average wind speeds are measured in October $(2.89 \mathrm{~m} / \mathrm{s})$ and June $(4.7 \mathrm{~m} / \mathrm{s})$, respectively. 


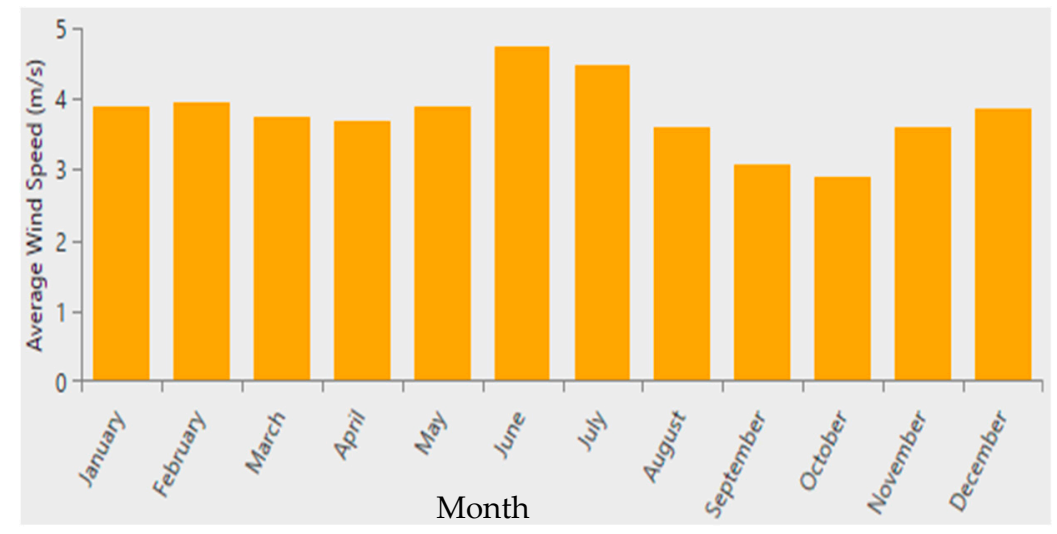

Figure 4. Average wind speed data.

\subsection{Load Profile}

The estimated load for Kibran Gabriel island is depicted in Figure 5 below. In this paper, considering the environmental conditions of the island and the community living there, loads are categorized as summer (June to October) load, winter (November to May) load, and weekend load. According to the estimation, a total of $16.00 \mathrm{kWp}$ power, of which $6.00 \mathrm{kWp}$ were deferrable power, $86.24 \mathrm{kWh} /$ day of winter load, $77.84 \mathrm{kWh} /$ day of summer load, and $62.22 \mathrm{kWh} /$ day of weekend loads were considered for the analysis. However, the scaled annual average load taken for the analysis was $76.94 \mathrm{kWh} /$ day. In addition, depending on the demand and its time of use, the load is categorized into primary and deferrable load. The primary loads are loads that require a certain amount of operating reserves to respond immediately to the sudden increase in the electric load and/or due to a decrease in power output [32], whereas deferrable loads permit some flexibility when power is insufficient. That is, deferrable load is the second priority after the primary load; however, its importance comes ahead of charging batteries. In this study, lighting loads, fans, sound amplifiers, refrigerators, sewing machines, flourmills, and water pumps were the major loads estimated for the analysis. However, the flourmill and sewing machines were excluded from the weekend loads considering the community religious practices in the island. Similarly, since the summer season is rainy and relatively cold, water pumps and fans were excluded from the summer load. In addition, water pumps are considered as deferrable load during the winter season. The estimated load frequency distribution is shown in Figure 6. According to the scaled frequency distribution, $75 \%$ of the distribution is $2 \mathrm{~kW}-5 \mathrm{~kW}$, and the remaining $25 \%$ is $6 \mathrm{~kW}-22 \mathrm{~kW}$.
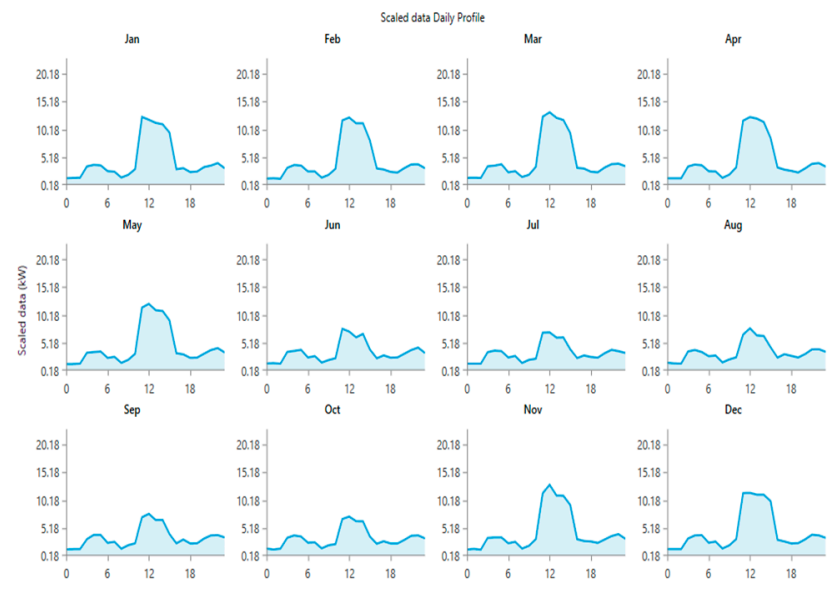

(a)

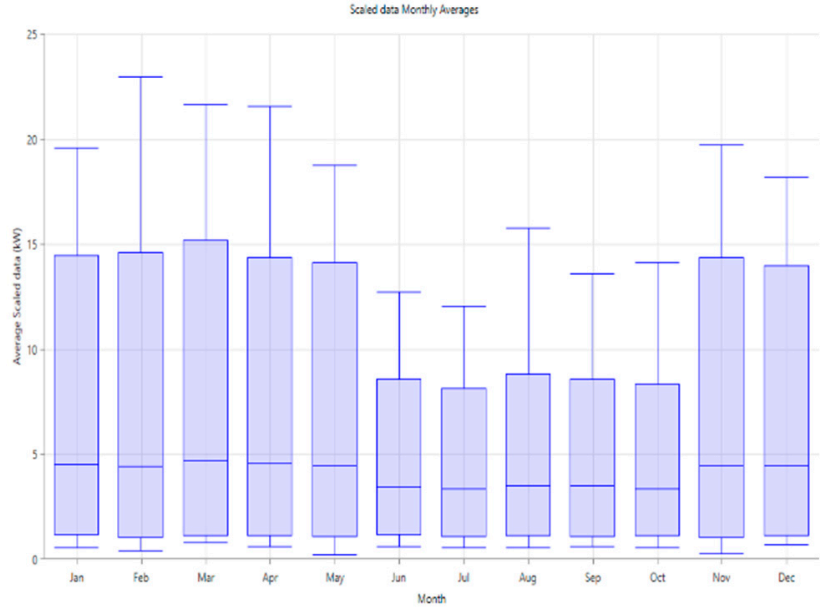

(b)

Figure 5. Scaled load profile for each month: (a) daily load profile, (b) monthly average. 


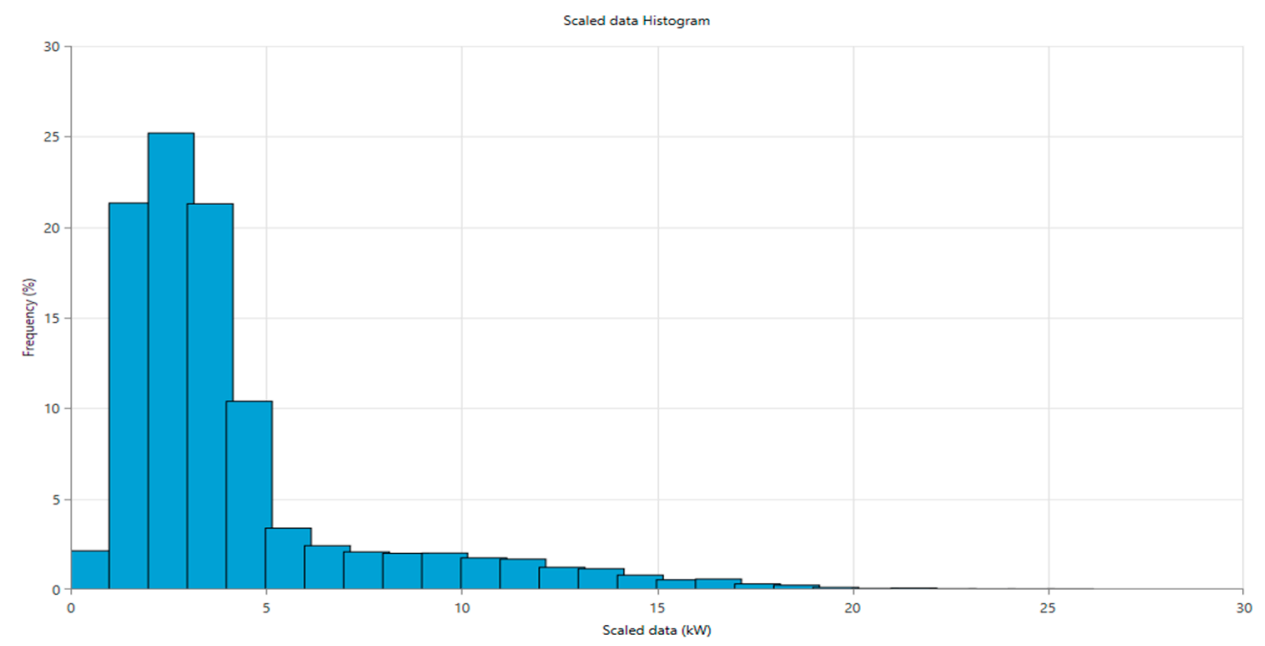

Figure 6. Frequency of the scaled load profile.

\subsection{Diesel Price}

Even though the diesel fuel price market in Ethiopia is relatively fluctuating from time to time, the government subsidizes it to minimize the cost. In this study considering the local market, a diesel fuel price of USD $0.62 / \mathrm{L}$ is taken for the analysis [33].

\subsection{Economic Assignment Criteria}

In this study real interest rate, capital recovery factor (CRF), net present cost (NPC), cost of energy (COE), and break-even grid extension distance were considered as the economic evaluation criteria [32,34].

\subsubsection{Annual Real Interest Rate}

As stated in Equation (1) HOMER Pro uses the annual real interest rate to determine discount factor and annualized costs from present costs.

$$
i=\frac{i^{\prime}-f}{1+f}
$$

where $i$ is annual real interest rate, $i^{\prime}$ is nominal interest rate, and $f$ is expected inflation rate $(\%)$.

\subsubsection{Capital Recovery Factor (CRF)}

The CRF is the ratio that is used to compute the present value of the annuity in the project lifetime.

$$
\operatorname{CRF}(i, t)=\frac{i(1+i)^{t}}{(1+i)^{t}-1}
$$

where $i$ is the annual real interest rate (\%), and $t$ is the number of years.

\subsubsection{Net Present Cost}

According to HOMER Pro, total NPC value signifies the project life cycle cost, and is computed using Equation (3). The cost includes the initial capital cost and the cash flow of the $t$-year over the factor (capital cost, fuel cost, operation cost, maintenance cost, replacement cost, etc.). Income contains electricity selling and salvage value after project life cycle.

$$
\begin{gathered}
N P C=C F_{0}+\left\{\frac{C F_{1}}{(1+i)^{1}}+\frac{C F_{2}}{(1+i)^{2}}+\frac{C F_{3}}{(1+i)^{3}}+\ldots+\frac{C F_{N}}{(1+i)^{N}}\right\} \\
=C F_{0}+\sum_{t=1}^{N} \frac{C F_{1}}{(1+i)^{t}}
\end{gathered}
$$


$C F_{0}$ is initial capital cost (USD); $C F_{t}$ is cash flow of $t$-year (USD); $t$ is number of year $(\mathrm{yr}) ; i$ is annual real interest rate $(\%) ; N$ is project lifetime $(\mathrm{yr})$.

\subsubsection{Cost of Energy}

HOMER Pro defines COE as the average cost per kWh of useful electrical energy generated by the system [15]. It is calculated by dividing total annualized cost (TAC) by total annualized useful electrical energy generated as shown in Equation (4).

$$
\begin{gathered}
C O E=\frac{T A C}{E_{\text {served }}} \\
T A C=N P C * \operatorname{CRF}(i, N) \\
E_{\text {served }}=E_{\text {pri }}+E_{\text {def }}+E_{\text {grid,sales }}
\end{gathered}
$$

TAC is the annualized value of NPC in USD/yr, $E_{\text {served }}$ is total electrical load served (primary load, deferrable load, energy sales to the grid) in $\mathrm{kWh} / \mathrm{yr}, C R F$ is capital recovery factor, $i$ is the real interest rate (\%) and $N$ is the project lifetime (yr).

\subsubsection{Grid-Extension Cost}

In this research, the grid extension cost is determined through the computation of breakeven grid extension distance (BGED). The BGED is the distance away from the grid at which the NPC of expanding the grid equals the NPC of a minigrid (stand-alone) system. When the grid extension distance exceeds the BGED, the minigrid system is more cost-effective [19,32]. The BGED is computed using Equation (7).

$$
B G E D=\frac{N P C \times C R F(i, N)-c_{\text {power }} \times E_{\text {demand }}}{c_{\text {cap }} \times \operatorname{CRF}(i, N)+c_{o m}}
$$

where total NPC of the minigrid system is in USD, CRF is capital recovery factor, $i$ real discount rate in $\%, N$ is project lifetime in years, $E_{\text {demand }}$ is total annual electrical demand including primary and deferrable in $\mathrm{kWh} / \mathrm{yr}, c_{\text {power }}$ is cost of power from gird in USD $/ \mathrm{kWh}$, $c_{c a p}$ is capital cost of grid extension in USD $/ \mathrm{km}, c_{o m}$ is O\&M cost of grid extension in $\mathrm{USD} / \mathrm{yr} / \mathrm{km}$.

\subsection{Electrical Assignment Criteria}

The descriptions below are some of the electrical assignment criteria references according to HOMER Pro [34].

\subsubsection{Renewable Fraction}

Renewable fraction (RF) is the fraction of the energy delivered to the load that is originated from renewable power sources. The percentage RF is expressed as shown in Equation (8).

$$
R F=\left(1-\frac{E_{\text {non-ren }}+H_{\text {non-ren }}}{E_{\text {served }}+H_{\text {served }}}\right) \times 100 \%
$$

$E_{\text {non-ren }}$ is nonrenewable electrical generation $(\mathrm{kWh} / \mathrm{yr}) ; H_{\text {non-ren }}$ is nonrenewable thermal generation $(\mathrm{kWh} / \mathrm{yr}) ; E_{\text {served }}$ is total electrical load served $(\mathrm{kWh} / \mathrm{yr}) ; H_{\text {served }}$ is total thermal load served $(\mathrm{kWh} / \mathrm{yr})$.

\subsubsection{Excess Electricity Fraction}

Excess electricity fraction $\left(f_{\text {excess }}\right)$ is the ratio of total excess electricity to total electrical production as shown in Equation (9).

$$
f_{\text {excess }}=\left(\frac{E_{\text {excess }}}{E_{\text {prod }}}\right) \times 100 \%
$$


where $E_{\text {excess }}$ is total excess electricity ( $\left.\mathrm{kWh} / \mathrm{yr}\right), E_{\text {prod }}$ is total electrical production ( $\left.\mathrm{kWh} / \mathrm{yr}\right)$.

\subsubsection{Capacity Shortage Fraction}

Capacity shortage fraction $\left(f_{c s}\right)$ is the ratio of total capacity shortage and total electrical demand as described in Equation (10). HOMER Pro considers a system viable only if the capacity shortage fraction is less than or equal to the maximum annual capacity shortage [35].

$$
f_{c s}=\left(\frac{E_{c s}}{E_{\text {demand }}}\right) \times 100 \%
$$

where $E_{c S}$ is total excess electricity $(\mathrm{kWh} / \mathrm{yr}), E_{\text {demand }}$ is total electrical production $(\mathrm{kWh} / \mathrm{yr})$.

\subsection{Sensitivity Variables}

In the rural areas, there is a low load demand which varies on a time basis [4]. On the other hand, solar radiation and wind speed vary depending on the daily environmental conditions. Sensitivity analysis monitors the effect of certain variables. That is, different values are assigned to these variables within a given range in order to assess their influence on the optimal minigrid system [19]. In this study, considering the optimal minigrid system, the sensitivity variables with the variations of GHI from 5.05 to $6.69 \mathrm{kWh} / \mathrm{m}^{2} /$ day, fuel price from USD 0.62 to $1 / \mathrm{L}$, and load consumptions from 76.94 to $107.72 \mathrm{kWh} /$ day are considered for the analysis.

\section{MiniGrid Hybrid Power System Description}

\subsection{MiniGrid System Schematic Diagram}

The schematic diagram of the minigrid power system is depicted in Figure 7. The minigrid system consists of wind power generator (WG), PV system (PVs), diesel generator (DG), power convertor (PC), storage system, primary and deferrable loads. PVs and WG are operated in parallel with DG, and AC coupled. PVs and WG supply power to the load to reduce the output of DG in order to reduce fuel intake [35]. Whereas the grid system is connected only for BGED analysis.

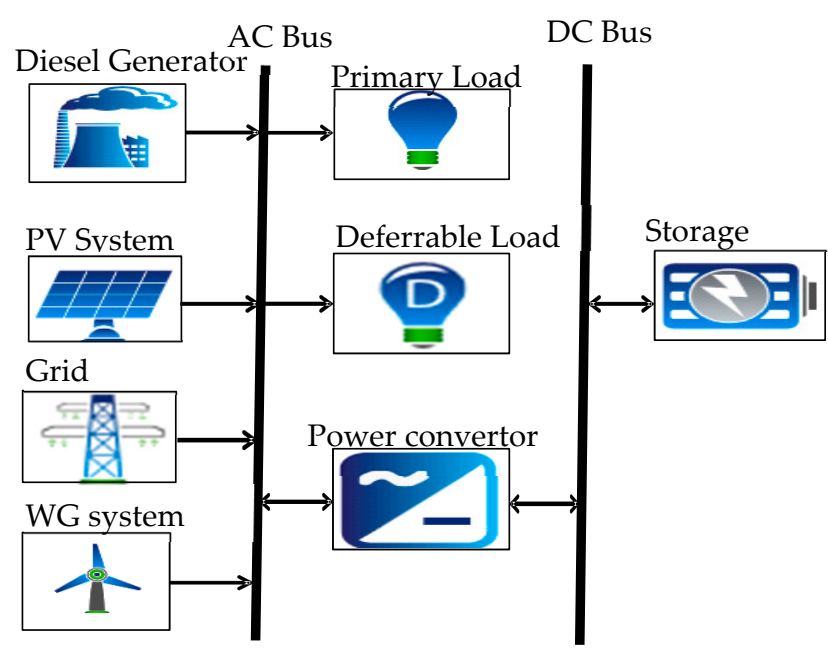

Figure 7. Schematic diagram of minigrid hybrid renewable energy system.

\subsection{PV System}

The PV module used for this study is CS6K-295MS mono-crystalline silicon solar cell module, which has the parameters shown in Table 1. The PV module is expected to 
serve for 25 years and the power output of the module $\left(P_{p v}\right)$ is calculated according to Equation (11) [36,37].

$$
P_{p v}=P_{p v, S T C} f_{p v} \frac{G_{T}}{G_{T, S T C}}\left[1+K_{P}\left(T_{C}-T_{S T C}\right)\right]
$$

where $P_{p v, S T C}$ is PV rated power power $(\mathrm{kWp}), f_{p v}$ is PV derating factor $(\%), G_{T}$ is solar irradiance on the surface of the PV module $\left(\mathrm{kW} / \mathrm{m}^{2}\right), G_{T, S T C}$ is standard solar irradiance $\left(1 \mathrm{~kW} / \mathrm{m}^{2}\right), K_{P}$ is the PV module temperature coefficient of power $\left(-0.40 \% /{ }^{\circ} \mathrm{C}\right), T_{\mathrm{C}}$ is temperature of the PV module $\left({ }^{\circ} \mathrm{C}\right), T_{\text {STC }}$ is temperature of the PV module under standard test conditions (STCs) $\left(25^{\circ} \mathrm{C}\right)$. In this study a derating factor of $85 \%$ was considered.

Table 1. Electrical parameters of the PV module [38].

\begin{tabular}{cc}
\hline \multicolumn{2}{c}{ Electrical Parameters } \\
\hline Rated power at STCs & $295 \mathrm{Wp}$ \\
Open circuit voltage, $V_{o c}$ & $39.5 \mathrm{~V}$ \\
Maximum power point voltage, $V_{m p}$ & $32.3 \mathrm{~V}$ \\
Short circuit current, $I_{S c}$ & $9.75 \mathrm{~A}$ \\
Maximum power point current, $I_{m p}$ & 9.14 \\
Temperature coefficient of maximum power & $-0.39 \% /{ }^{\circ} \mathrm{C}$ \\
Temperature coefficient of open circuit voltage & $-0.29 \% /{ }^{\circ} \mathrm{C}$ \\
Temperature coefficient of short circuit current & $0.05 \% /{ }^{\circ} \mathrm{C}$ \\
Module efficiency & $18.02 \%$ \\
\hline
\end{tabular}

\subsection{Wind Generator System}

A Bergey (XL10)) wind turbine of $10 \mathrm{kWp}$ AC power output at $12 \mathrm{~m} / \mathrm{s}$, a minimum operating wind speed of $2.5 \mathrm{~m} / \mathrm{s}$, and 20 years of lifetime was considered for this analysis [39]. The power curve of the wind turbine, and the wind speed at the hub $\left(U_{\text {hab }}\right)$ are shown in Figure 8, and Equation (12), respectively.

$$
U_{h u b}=U_{r e f} \times\left(\frac{H_{h u b}}{H_{r e f}}\right)^{\alpha}
$$

where $U_{\text {ref }}$ is reference wind speed $(\mathrm{m} / \mathrm{s})$, given by NASA measurements at a reference height of $50 \mathrm{~m}$ from the surface $\left(H_{r e f}\right) . H_{h u b}$ is the hub height ( $30 \mathrm{~m}$ in this case) where the wind speed at the hub is calculated. $\alpha$ is surface roughness - the value is set to $0.14[40,41]$.

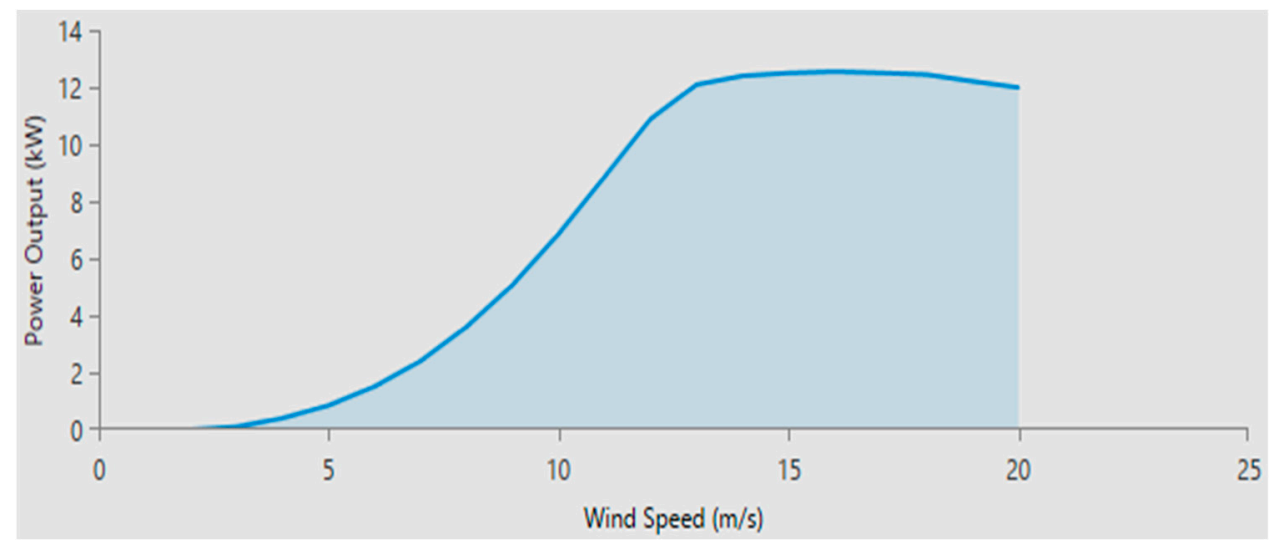

Figure 8. Power curve of the wind turbine.

\subsection{Diesel Generator}

Due to the fact that the PV and wind modules have intermittent natures, the diesel generator will ensure the off-grid hybrid power system's stability and reliability. In addi- 
tion, in this study the diesel generator is considered as the base case reference for relative comparison using LCOE and NPC. In HOMER Pro, we input the load profile and select "Autosize Genset" for the DG specification, and set the maximum annual capacity shortage fraction of the system operational constraint to $0 \%$. The generic $10 \mathrm{~kW}$ diesel generator with efficiency of $30 \%$, and fuel curve slope of $0.286 \mathrm{~L} / \mathrm{h} / \mathrm{kW}$ were considered for the initial case from HOMER Pro catalogue. Then, the software automatically adjusted to the proper capacity and fulfilled the system's operational constraints.

\subsection{Power Convertor and Storage System}

A bi-directional DC-AC converter was employed for power conversion. When surplus power is generated by PV, diesel, and/or WG, the excess AC power is converted to DC and stored in a battery, to supply it back when necessary. A conversion efficiency of $95 \%$ and 15 years of lifetime are assumed in the simulation [33]. In this study, a Li-ion battery with a round-trip efficiency of $90 \%$, an initial state of charge of $100 \%$, a minimum SOC of $20 \%$, and 10 years of lifetime with negligible O\&M cost is considered [42].

\subsection{Grid System}

Kibran Gabriel island is located about $11 \mathrm{~km}$ from Bahir Dar city; however, extending the grid from the city to Kibran has not yet been realized due to Lake Tana. In this study, we consider the grid system to compute BGED using Equation (7) so as to compare the proposed off-grid systems cost with the grid extension cost.

\subsection{Dispatch Strategy}

Excess energy from renewables is always expected to charge the battery, and one of the most important decisions that the dispatch system must make is when to charge the batteries with energy from the generator. In this research, we look at a Combined Dispatch (CD) approach that combines Load Following (LF) and Cycle Charging (CC) dispatch strategies [43]. In the CC strategy, whenever the generator needs to be on to meet the net load (load minus intermittent renewable power), it operates at full capacity and the surplus power charges the battery bank. In LF strategy, the generator is dispatched just to fulfill the net load and any operational reserve needs. The CD strategy determines whether to charge the battery with the generator based on the current net load, employing the CC strategy when the net load is low and the LF strategy when the net load is high [20,32].

\section{Component Cost and Financial Assumption}

\subsection{MiniGrid Component Cost}

Taking into account the local market and the reduction in system component costs from time to time, the summary of component costs depicted in Table 2 were considered for the simulation analysis. As shown in the table, the cost includes capital cost, replacement cost, and operation and maintenance (O\&M) cost. The capital cost of the PV (USD 900/kW) includes the PV inverter cost, and the capital cost of the WG (USD 3500/kW) includes wind turbine, $30 \mathrm{~m}$ tower and wind invertor costs. The estimate costs of all the components also include transportation and installation costs.

Table 2. Component cost.

\begin{tabular}{cccc}
\hline Components & Capital Cost & Replacement Cost & O\&M Cost \\
\hline PV system [44] & USD 900/kW & - & USD 900 $/ \mathrm{kW} / \mathrm{yr}$ \\
WG system [33] & USD 3500/kW & USD 3000/kW & USD 20/kW $/ \mathrm{yr}$ \\
Storage system [42] & USD 630/kWh & USD 600/kWh & 0 \\
Power converter [33] & USD 650/kW & USD 600 $/ \mathrm{kW}$ & USD 6/kW $/ \mathrm{yr}$ \\
Diesel generator [45] & USD 500/kW & USD 400 $/ \mathrm{kW}$ & USD 0.02 $/ \mathrm{h}$ \\
\hline
\end{tabular}




\subsection{Grid Extension Component Cost}

In this study, in order to verify the feasibility of minigrid power supply to Kibran Gabriel island, BGED was determined using Equation (7). For the BGED analysis, the minimum grid extension capital cost of USD 23,000/ km and O\&M cost of USD 200/ km were considered [46]. With the government subsidies, a grid power price of USD $0.06 / \mathrm{kWh}$ is taken for the analysis according to Ethiopian Electric Utility revised tariff [47].

\subsection{Interest Rate and Inflation Rate}

As depicted in Figure 9a,b the nominal interest rate and inflation rate, respectively, announced by National Bank of Ethiopia [48] for the past seven years (2013-2019) were considered for the simulation analysis. The minimum nominal interest rate of $11.88 \%$, the maximum nominal interest rate of $13.5 \%$, and the average of the nominal interest rate for the considered period was $12.59 \%$. Similarly, the minimum, maximum, and average inflation rate for the considered period were $7.4 \%, 14.6 \%$ and $10.51 \%$, respectively. In this paper, the project lifetime of 25 years, the average values of nominal interest rate $(12.59 \%)$ and the inflation rate $(10.51 \%)$ were used to calculate the annual real interest rate using Equation (1).

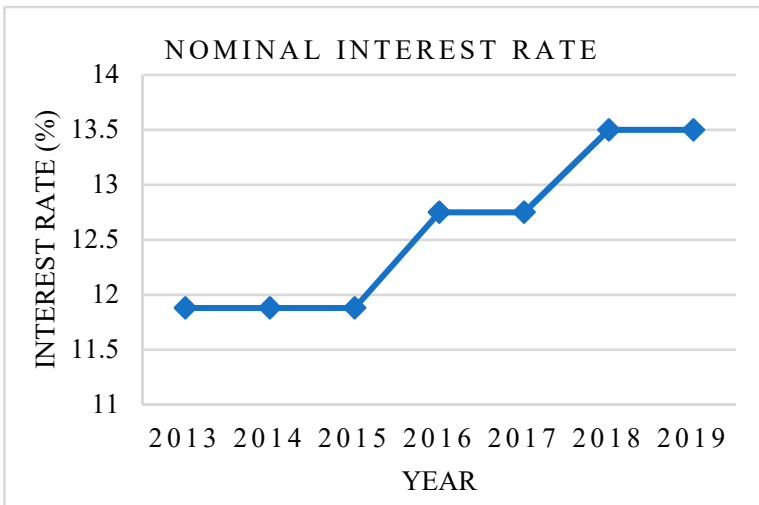

(a)

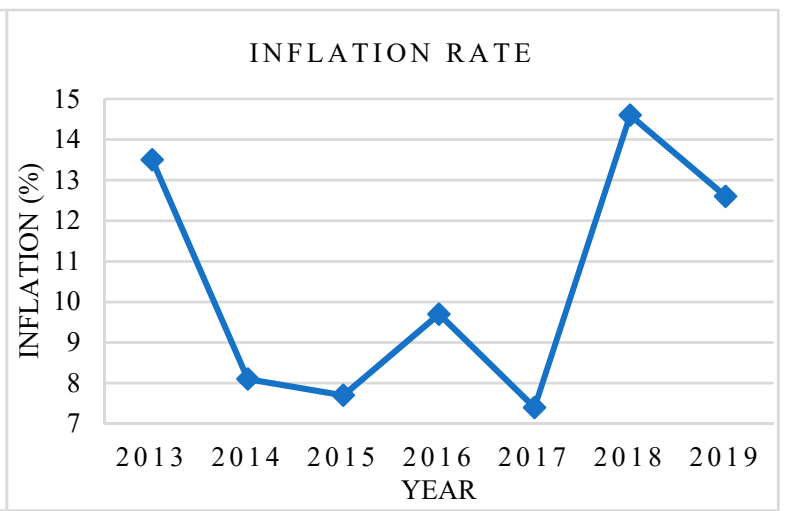

(b)

Figure 9. (a) Nominal interest rate, (b) Inflation rate.

\section{Simulation Results and Discussion}

The proposed minigrid system depicted in Figure 7 is optimized using HOMER Pro based on LCOE and NPC. Once the optimal minigrid system was determined, various sensitivity variables were considered to check the effect on the optimal system. According to the simulation result, the possible configurations for the selected site are discussed as follows:

\subsection{Optimization Results}

\subsubsection{Stand-Alone Diesel System}

As depicted in Table 3, when only diesel power generation is considered the LCOE of USD $0.346 / \mathrm{kWh}$, NPC of USD 235,734 and $38.3 \mathrm{t} / \mathrm{yr}$ of pollutant emission gases were the optimization results. However, since the simulation result of only diesel system is the reference for other configurations, to make it cost effective excesses energy of not more than $3 \%$ and a maximum capacity shortage of $0.09 \%$ were considered. Once the optimization result of the stand-alone diesel system was determined, its feasibility relative to the grid extension cost was determined using BGED analysis. According to BGED analysis, a stand-alone diesel system is relatively feasible for the selected site compared to grid extension cost when the electrification distance is farther than $3.11 \mathrm{~km}$, as shown in Figure 10a. However, due to the high level of polluting gases emitted, the high operating 
fuel cost, and the tourist-attracting nature of the island, the stand-alone diesel system is not the favored solution to electrify the specified island.

Table 3. Possible configurations for the selected site.

\begin{tabular}{|c|c|c|c|c|c|c|}
\hline Minigrid System & $\begin{array}{c}\text { LCOE } \\
\text { (USD/kWh) }\end{array}$ & NPC (USD) & $\begin{array}{c}\text { Emission } \\
(\mathrm{kg} / \mathrm{yr})\end{array}$ & RF (\%) & $\begin{array}{l}\text { Unmet } \\
\text { Load (\%) }\end{array}$ & BGED $(\mathbf{k m})$ \\
\hline PV/diesel/battery & 0.175 & 119,139 & 5159 & 86.4 & 0 & 1.25 \\
\hline PV/battery & 0.258 & 175,506 & 0 & 100 & 0.09 & 2.15 \\
\hline $\mathrm{PV} /$ wind/diesel/battery & 0.304 & 207,388 & 18,324 & 55.3 & 0 & 2.66 \\
\hline PV/wind/battery & 0.323 & 219,736 & 0 & 100 & 0.09 & 2.86 \\
\hline Stand-alone diesel & 0.346 & 235,734 & 38,261 & 0 & 0.02 & 3.11 \\
\hline
\end{tabular}

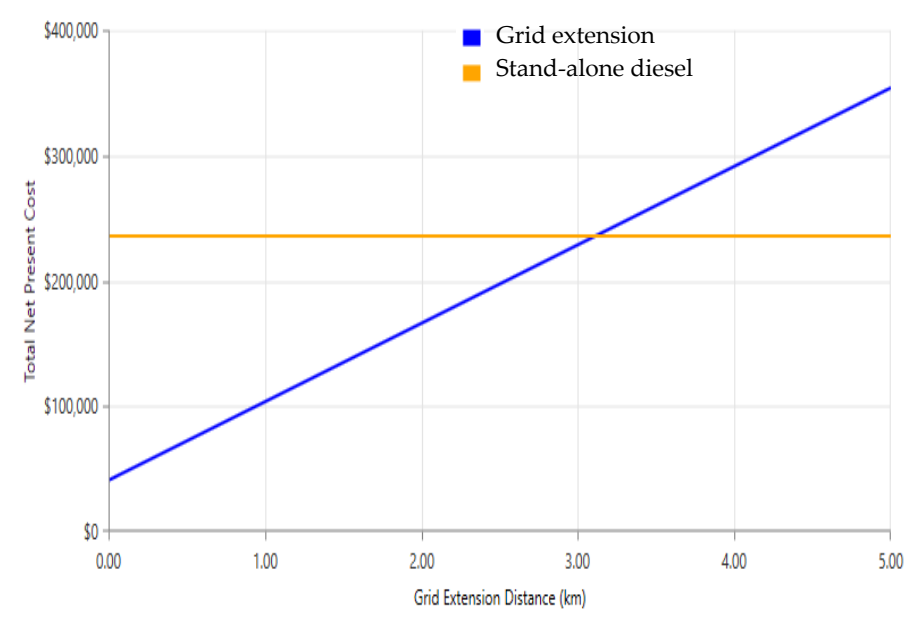

(a)

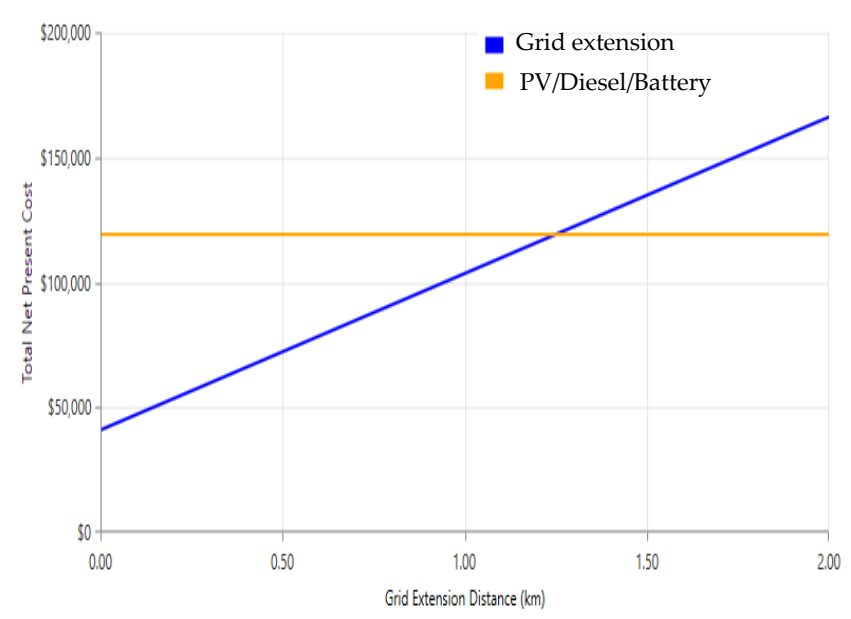

(b)

Figure 10. BGED relative to (a) Stand-alone diesel system, (b) PV/Diesel/Battery system.

\subsubsection{PV/Wind/Battery System}

The PV/wind/battery system is the other alternative to electrify the specified site. According to the simulation analysis this system was optimized to the LCOE of USD $0.323 / \mathrm{kWh}$ and NPC of USD 219,736. The PV/wind/battery system is free of pollutant gas emissions, and economically feasible compared with the stand-alone diesel system. However, the PV/wind/battery system demands a relatively high initial investment cost (USD 129,986) due to its high component cost compared with the other configurations considered in this study.

\subsubsection{PV/Wind/Diesel/Battery System}

Of the hybrid systems considered in this study, the PV/wind/diesel/battery system, having LCOE of USD 0.304/kWh, NPC of USD 207,388, and emissions of 18,324 kg/yr, was composed of a better energy mix than the other systems discussed in Sections 6.1.2, 6.1.4 and 6.1.5. Even though the PV/wind/diesel/battery system had a better in energy mix than the other configurations considered in this study, the higher magnitudes of NPC, LCOE and emissions, as shown in Table 3, could lead us to search for another cost effective-alternative to electrify Kibran Gabriel island.

\subsubsection{PV/Battery System}

The PV/battery system is the second-lowest-cost alternative for electrifying the specified island. The simulation result indicated that the LCOE of $0.258 \mathrm{USD} / \mathrm{kWh}$ NPC of USD 175,506 with zero pollutant emission gasses. In this system, in order to deliver the desired power to the community with $0 \%$ capacity shortage, a PV size of $60 \mathrm{kWp}$, and a 
battery size of $75 \mathrm{kWh}$ were required. However, due to the intermittent nature of solar energy, the PV/Battery system must be of a relatively big size to cope up the day and night loads. Having a big size leads the system to have high excess electricity $(66.3 \%)$. On the other hand, when we calculated a capacity shortage of $5 \%$, the excess electricity was reduced to $35.6 \%$ and the unmet load was $4.5 \%$. This assured that in the PV/battery system, when $0 \%$ capacity shortage is considered, the system size will be higher. When a capacity shortage of greater than zero is considered, the system is incapable of handling peak loads. Considering these limitations, the authors continued to search for another optimal solution to electrify the island.

\subsubsection{PV/Diesel/Battery System}

The initial simulation conditions considered for this study were: annual average solar radiation of $5.94 \mathrm{kWh} / \mathrm{m}^{2} /$ day; annual average wind speed of $3.78 \mathrm{~m} / \mathrm{s}$; nominal interest rate of $12.59 \%$; primary load demand of $76.94 \mathrm{kWh} /$ day; and a project lifetime of 25 years. From the feasible system configurations shown in Table 3, the PV/diesel/battery system offers the optimal solution for the proposed system. The detailed is presented in Table 4. As depicted in Table 4, the PV/diesel/battery system could deliver the required power to the island with LCOE of 0.175 USD/kWh, NPC of USD 119,139 and emissions of 5159 $\mathrm{kg} / \mathrm{yr}$. When these parameters compared to the simulation outputs of the stand-alone diesel system, the pollutant emission gasses, NPC, and LCOE were reduced by $86.52 \%$, $49.46 \%$ and $49.42 \%$, respectively. The BGED, and a detailed cost summary of components, are shown in Figures 10b and 11, respectively.

Table 4. Simulation result of optimal minigrid system, architecture, and cost.

\begin{tabular}{ccccccccc}
\hline $\begin{array}{c}\text { System } \\
\text { Architecture }\end{array}$ & $\begin{array}{c}\text { PV } \\
\mathbf{( k W )}\end{array}$ & $\begin{array}{c}\text { DG } \\
(\mathbf{k W})\end{array}$ & $\begin{array}{c}\text { Battery } \\
\mathbf{( N o )}\end{array}$ & $\begin{array}{c}\text { Converter } \\
\mathbf{( k W )}\end{array}$ & $\begin{array}{c}\text { LCOE } \\
(\mathbf{U S D} / \mathbf{k W h})\end{array}$ & $\begin{array}{c}\text { NPC } \\
\text { (USD) }\end{array}$ & $\begin{array}{c}\text { Operating } \\
\text { Cost (USD/yr) }\end{array}$ & $\begin{array}{c}\text { Initial } \\
\text { Capital (USD) }\end{array}$ \\
\hline $\mathrm{PV} /$ diesel/battery & 25 & 10 & 40 & 5 & 0.175 & 119,139 & 3196 & 55,872 \\
\hline
\end{tabular}

COST SUMMARY

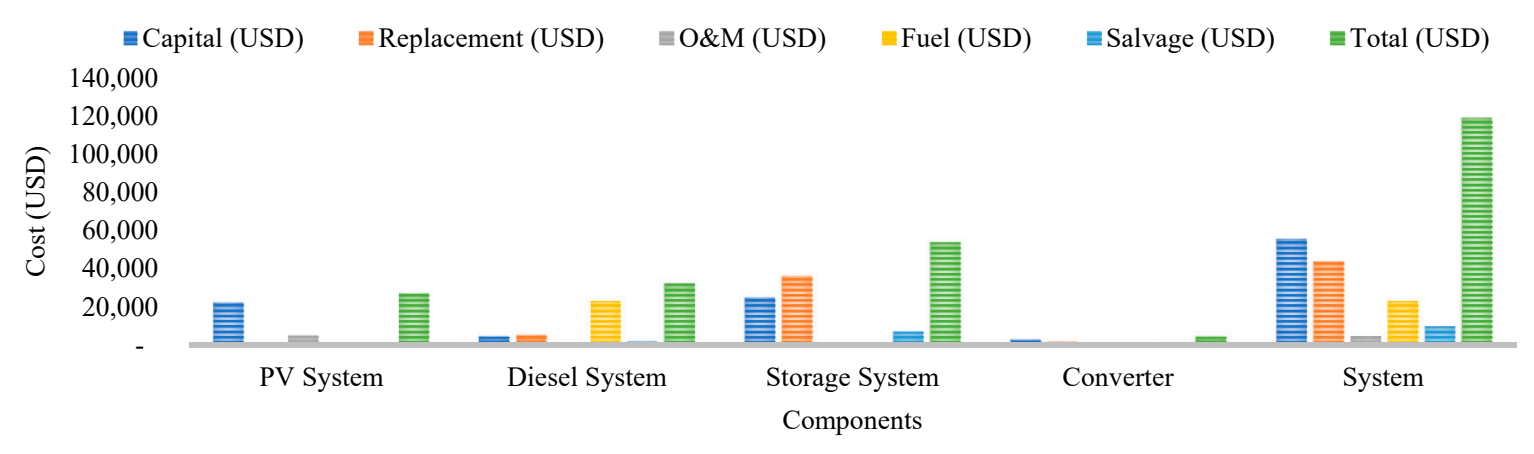

Figure 11. Cost summary of PV/diesel/battery system components.

On the other hand, the technical performance of the PV/Diesel/battery system was simulated considering the winter and summer environmental conditions with the corresponding loads. The result shown in Figure 12 displays the detailed time series analysis of the power outputs of the PV and diesel system, battery charging and discharging, and total loads (including primary and deferrable) for the winter's day of 3 January. In the winter time, due to high solar radiation (up to $6.68 \mathrm{kWh} / \mathrm{m}^{2} /$ day) and clearance index (up to 0.69 ) in the country, specifically at the study site, the PV system generates significant amounts of power from 06:00 to 18:00. The deferrable loads $(6 \mathrm{~kW})$ include water pumps were served from 06:00 to 11:00 when there is excess power. However, during the peak 
loading condition (10:00 to 12:00) the diesel generator supported the PV system to fulfill the power demand and the battery charging power started to decline at 11:00. During the nighttime, from 18:00 to 06:00 the load demand receives power from battery and/or diesel generator. As shown in Figure 12, starting from 17:00 to 04:00 the battery discharged to deliver the required power to the load demand. However, from 04:00 to 06:00, when the battery was incapable of fulfilling the load demand, the diesel generator started to produce the required electricity.

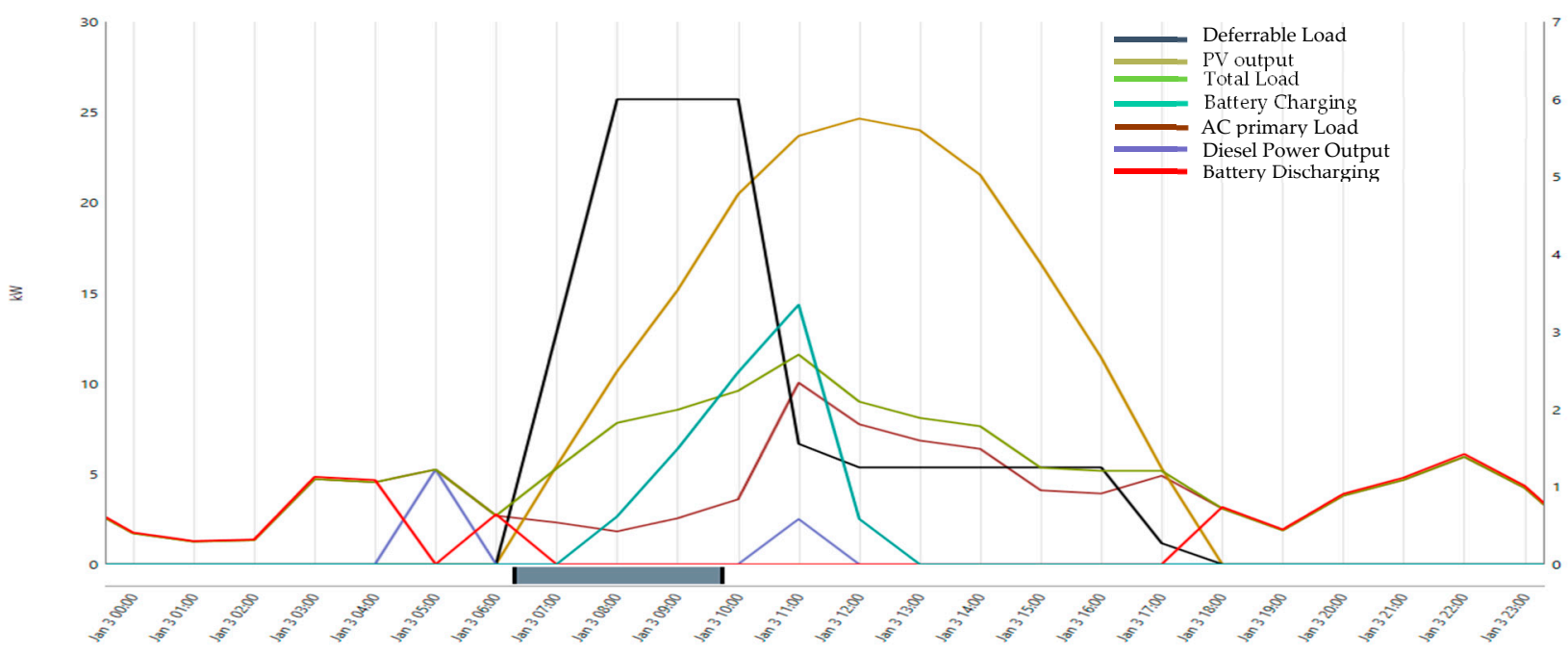

Figure 12. Daily time series analysis for winter season.

Similarly, the time series analysis of power outputs of the PV and diesel system, battery charging and discharging, and total loads for the summer's day of 6 July is depicted as follows in Figure 13.

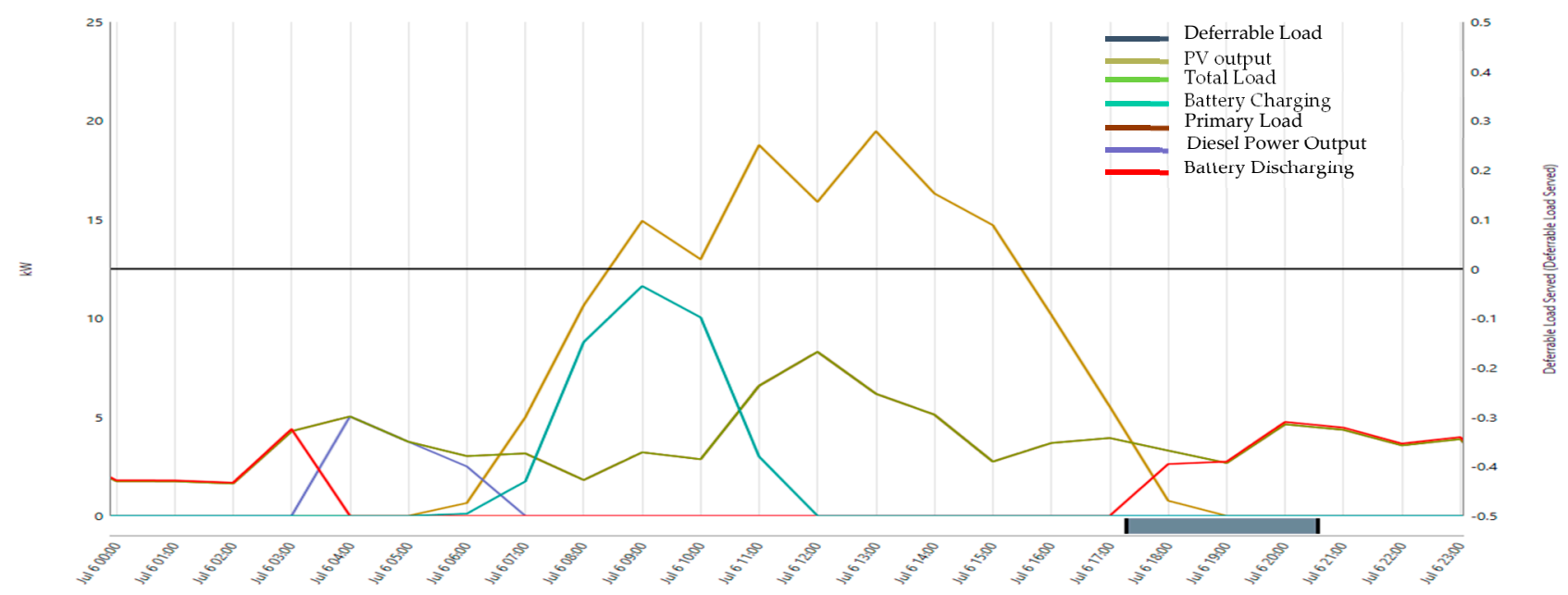

Figure 13. Daily time series analysis for summer season.

During the summer season in the study area experiences a relatively high amount of rain, with lower solar radiation $\left(5.05 \mathrm{kWh} / \mathrm{m}^{2} /\right.$ day) and lower clearance index (0.48). As shown in Figure 13, the total load and the primary load are the same (overlapping) because the deferrable loads (water pumps) were neglected since the summer is rainy season in the study area. From the time series analysis, we observed that the main power source during the daytime (07:00 to 17:00) was the PV system, whereas for the remaining time, from 17:00 to 03:00 the battery system, and from 03:00 to 07:00 the diesel generator contributed the power demanded by the load. As we can observe from Figures 12, 13 and 14a, the PV 
power output of the summer season was relatively lower than the PV power output of the winter season.

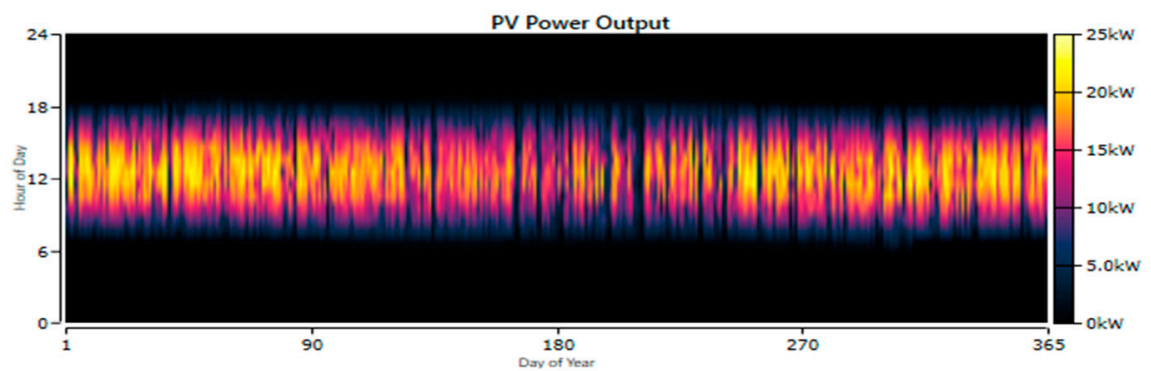

(a)

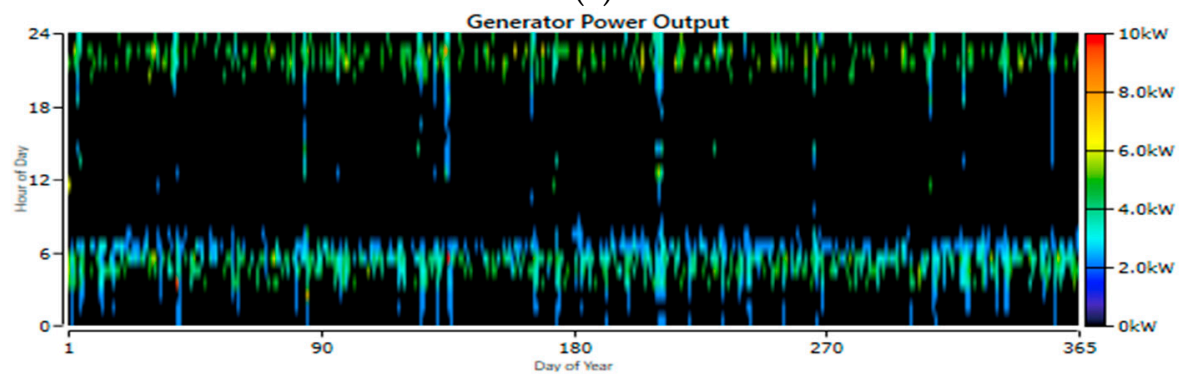

(b)

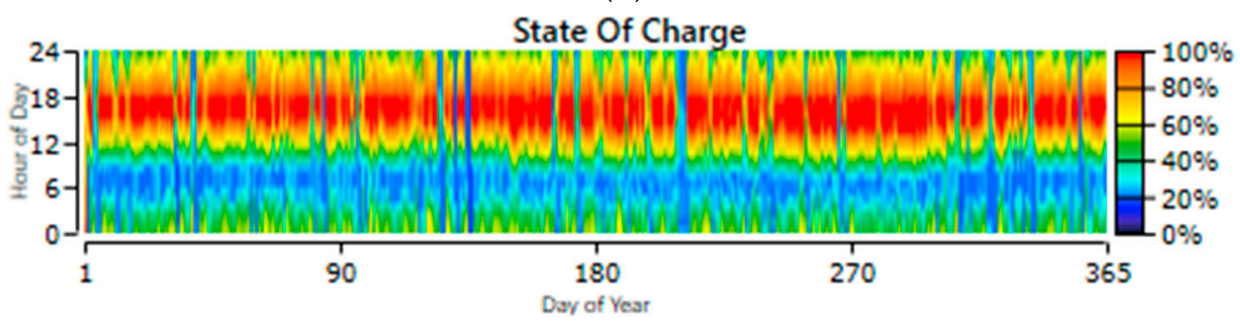

(c)

Figure 14. Yearly power delivering status. (a) PV system, (b) diesel generator, (c) battery.

The yearly power contributions of the PV and diesel generator, and the state of charge of the battery for the PV/diesel/battery hybrid system were depicted in Figure 14. As shown in Figure 14a during, the daytime, especially from 8:00 to 16:00, the PV system contributed a relatively high power share, whereas the remaining time and the peak load conditions were handled by the diesel generator and the battery system, as depicted in Figure $14 \mathrm{~b}, \mathrm{c}$.

\subsection{Sensitivity Analysis}

The optimization process that enabled us to find out the optimal solution (PV/diesel/ battery system) used average values such as the annual average solar radiation of $5.94 \mathrm{kWh} / \mathrm{m}^{2} /$ day, the annual average wind speed of $3.78 \mathrm{~m} / \mathrm{s}$, a primary load demand of $76.94 \mathrm{kWh} /$ day, an ad fuel cost of USD 0.6/L. However, in the real system the solar radiation and wind speed vary depending on the daily environmental conditions, the load demand varies dynamically, and the fuel cost fluctuates depending on the world's fuel market. Having this in mind, the effects of the variations of GHI, fuel price, and load consumption on the optimal PV/diesel/battery system were considered in the sensitivity analysis.

\subsubsection{Global Horizontal Irradiance (GHI)}

Based on the data taken from National Renewable Energy Laboratory Database, the minimum GHI (5.05 kWh/m²/day) and the maximum GHI $\left(6.69 \mathrm{kWh} / \mathrm{m}^{2} /\right.$ day $)$ were the ranges on which the sensitivity variables varied. Considering $\pm 7 \%$ changes of the average 
value $\left(5.94 \mathrm{kWh} / \mathrm{m}^{2} /\right.$ day), the sensitivity variables of GHI were 5.05, 5.46, 5.94, 6.35, $6.68 \mathrm{kWh} / \mathrm{m}^{2} /$ day. As we can observe from the optimal plot (Figure 15), maintaining the scale average load $(76.96 \mathrm{kWh} /$ day) when diesel price is minimum (USD $0.6 / \mathrm{L}$ ) and GHI is maximum $\left(6.68 \mathrm{kWh} / \mathrm{m}^{2} /\right.$ day), the minimum LCOE is USD $0.170 / \mathrm{kWh}$. On the contrary, when the diesel price is maximum (USD 1/L) and GHI is minimum $\left(5.05 \mathrm{kWh} / \mathrm{m}^{2} /\right.$ day) the maximum LCOE is USD $0.198 / \mathrm{kWh}$. The effect of GHI variation on LCOE, NPC and RF can also be observed from Figures 16 and 17. When we set the load to $100.01 \mathrm{kWh} /$ day and the diesel price USD 0.62L, the LCOE was lowered to USD 0.168/ kWh and RF increased to $79.4 \%$, as depicted in Figure 16. Keeping the minimum diesel price and load but increasing GHI (from 5.05 to $6.68 \mathrm{kWh} / \mathrm{m}^{2} /$ day) will reduce the NPC from USD 124,086 to USD 116,059 (Figure 17), the LCOE from USD 0.182 to USD 0.170/kWh (Figure 15), and increase the RF from $82.7 \%$ to $87.3 \%$.

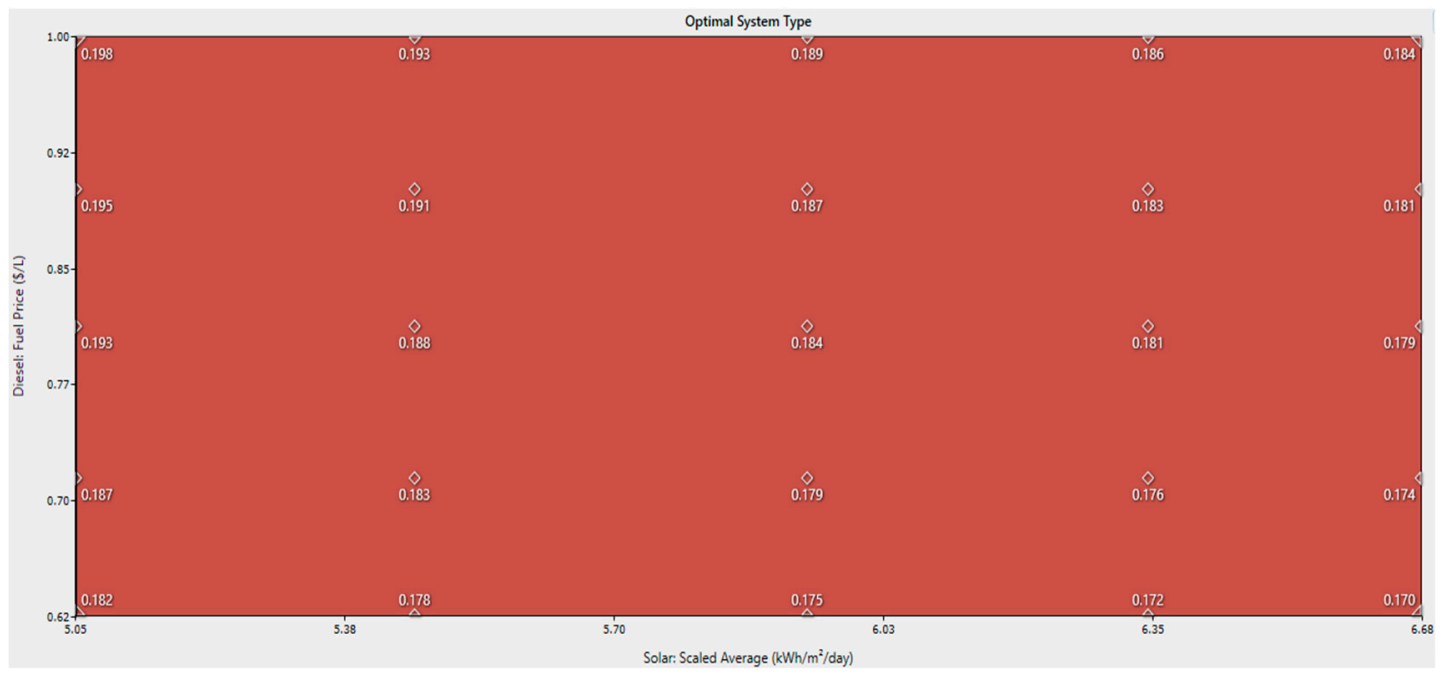

Figure 15. PV/diesel/battery system sensitivity with GHI and diesel price variations.

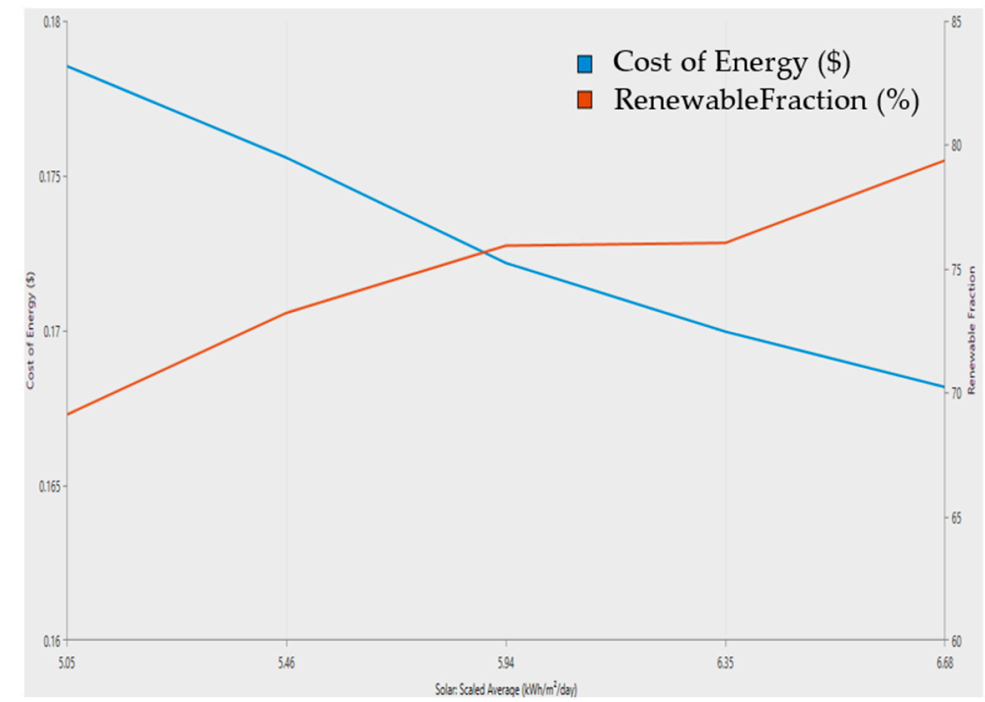

Figure 16. LCOE and RF related to GHI variations. 


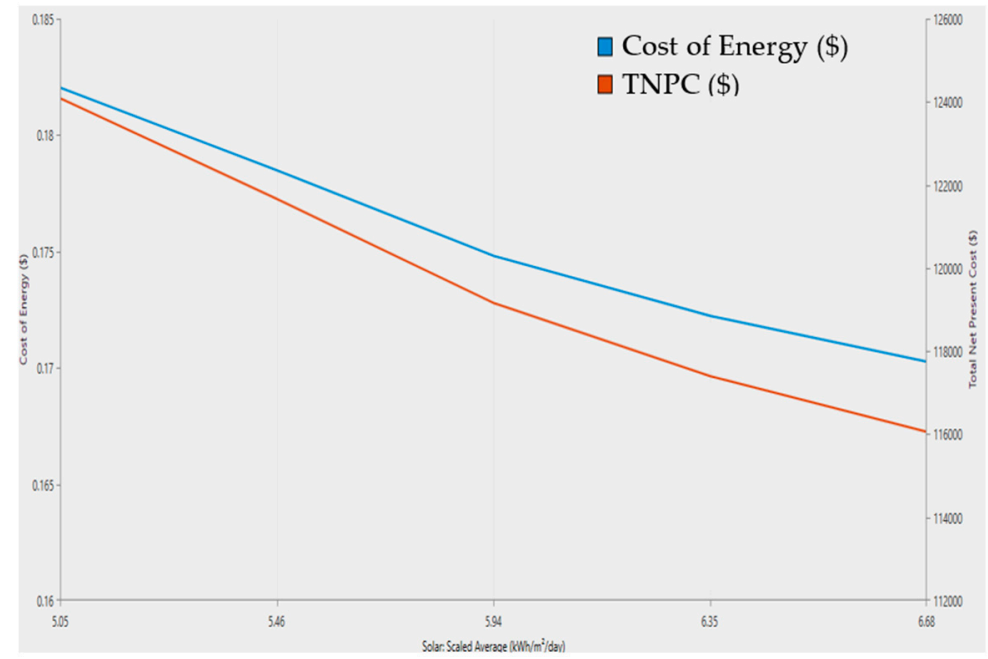

Figure 17. LCOE and TNPC related to GHI variations.

\subsubsection{Diesel Price}

Considering the local market conditions, we set the fuel price to vary from USD $0.62-1 / \mathrm{L}$ in steps of $15 \%$ change from the minimum value (USD $0.62 / \mathrm{L}$ ). Keeping the minimum load (76.94 kWh/day) and minimum GHI $\left(5.05 \mathrm{kWh} / \mathrm{m}^{2} /\right.$ day), when the diesel price varied from USD 0.62 to $1 / \mathrm{L}$ the LCOE increased from USD 0.182 to $0.198 / \mathrm{kWh}$ (Figure 15) and NPC also increased to USD 134,656. Similarly, the line plot of diesel price variation effect on the LCOE and NPC was presented in Figure 18 above. Maintaining the average GHI of $5.94 \mathrm{kWh} / \mathrm{m}^{2} /$ day and load of $76.94 \mathrm{kWh} /$ day, when the diesel price varied from USD 0.62 to $1 / \mathrm{L}$, relative increments of LCOE and NPC from the optimal value were observed in Figure 18.

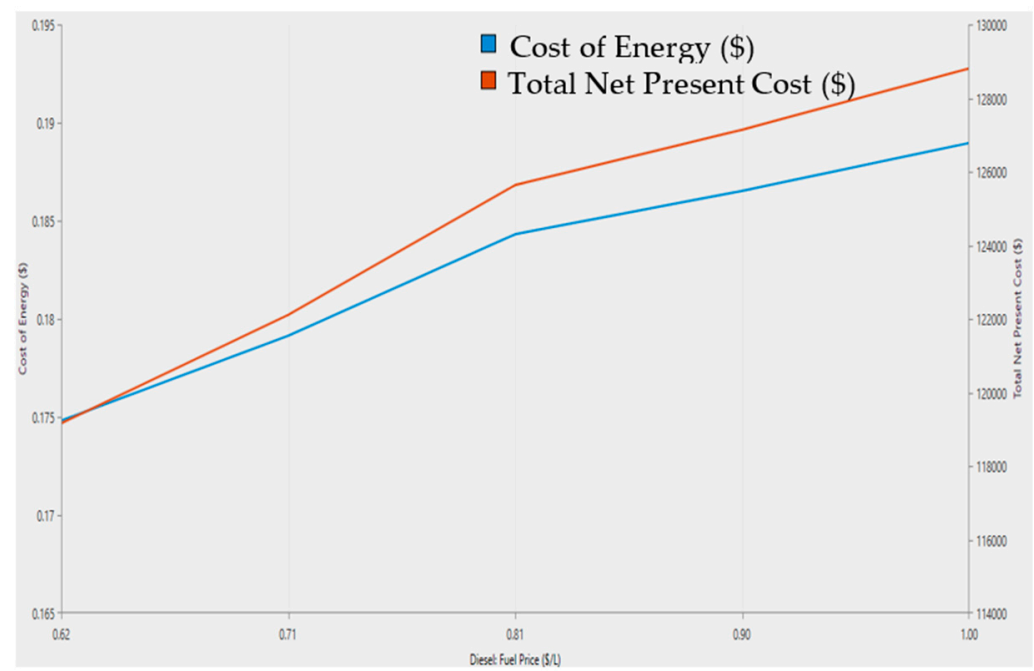

Figure 18. LCOE and TNPC related to diesel price variations.

\subsubsection{Load Consumption}

As shown in Figure 19, when the load varied from 76.94 to $107.72 \mathrm{kWh} /$ day in steeps of $10 \%$ change from the minimum (keeping the current diesel price of USD $0.62 / \mathrm{L}$ and average GHI of $5.94 \mathrm{kWh} / \mathrm{m}^{2} /$ day) the LCOE showed a small reduction from USD 0.175 to $0.171 / \mathrm{kWh}$, while the fuel intake increased from $1895 \mathrm{~L} / \mathrm{yr}$ to $4473 \mathrm{~L} / \mathrm{yr}$. Similarly, the NPC increased from USD 119,160 to USD 154,780. As electricity demand rises, DG will increase the power generation to meet the demand. This causes the RF to decline, the fuel consumption and NPC to increase, and COE to become relatively decreased. 


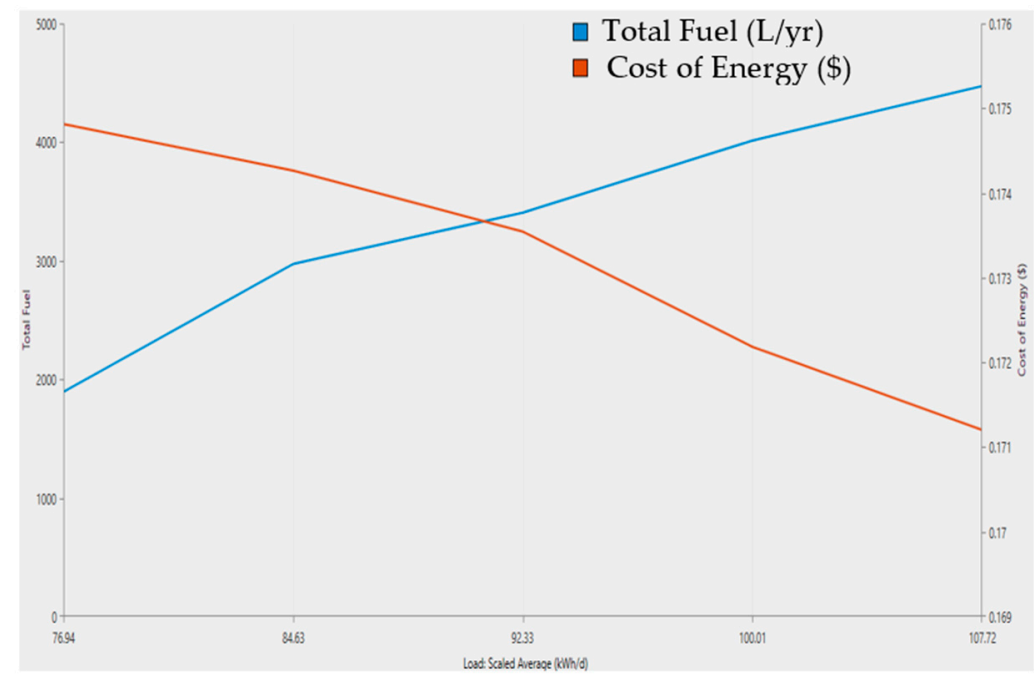

Figure 19. Total fuel usage and LCOE related to load variations.

As we have seen from the sensitivity analysis, the variations in the GHI, diesel fuel price and load have been considered to check the capabilities of the PV/diesel/battery system to withstand those fluctuations. When these sensitivity parameters were considered, the new optimization results achieved were LCOE of USD 0.179/kWh, NPC of USD 151,468, and RF of $69.1 \%$. These results prove that the PV/diesel/battery system can operate reasonably well for the Kibran Gabriel island during the specified project lifetime.

\section{Conclusions}

Rural electrification in the remote regions of Ethiopia through grid extension is not economically feasible because of the dispersed population, difficult geographic terrain and low load demand in the existing conditions. On the other hand, delivering electricity from SHS and diesel generators only for lighting for a short period of time will not bring the expected economic development. Having these controversies in mind, in this study, in addition to lighting loads, sewing machines, flourmills, water pumps, and refrigerators for preserving fishery products were considered in the load estimation of Kibran Gabriel island.

Based on the estimated load demand and the environmental conditions of the island, stand-alone diesel, PV/battery, PV/wind/battery, PV/diesel/battery, and PV/wind/diesel/ battery systems were considered in the analysis. The following concluding remarks are drawn.

- Of all the minigrid systems considered in this study, the PV/diesel/battery system, having a size of $25 \mathrm{~kW}$ of PV, $10 \mathrm{~kW}$ of DG, and 40 batteries of $1 \mathrm{kWh}$ each is the optimal minigrid system, with LCOE of USD $0.175 / \mathrm{kWh}$, NPC of USD 119,139, and RF of $86.4 \%$. Relatively, it is the lowest cost system among the considered configurations.

- Compared to the base case stand-alone diesel system (LCOE of USD 0.346/kWh, NPC of USD 235,734), the optimal PV/diesel/battery system will reduce pollutant emissions by $33,102 \mathrm{~kg} / \mathrm{yr}$.

- In addition to PV/diesel/battery system, the PV/battery, PV/wind/battery, and $\mathrm{PV} /$ wind/diesel/battery systems are economically feasible compared to the standalone diesel system. However, the initial investment cost of the stand-alone diesel system is relatively the lowest.

- According to the BGED analysis, grid-extension to the island within the specified project lifetime is extremely costly compared to all the proposed options considered in this study.

- Once the optimal configuration is determined, the optimal minigrid sensitivity for the variations of GHI, diesel price, and load consumption was considered in the sensi- 
tivity analysis. The new optimization results due to the variations of the sensitivity parameters were modified to LCOE of USD $0.179 / \mathrm{kWh}$, NPC of USD 151,468 and RF of $69.1 \%$. These optimization results showed that the system will operate reasonably well with the variations of GHI, diesel price, and load consumption. However, the impacts of renewable energy resources on the reliability and quality of power, and refining the estimated loads for practical implementation will be the subjects of future works.

Author Contributions: Conceptualization, C.-C.K. and T.M.B.; methodology, T.M.B. and C.-C.K.; formal analysis, T.M.B. and C.-H.W.; resources, C.-H.W., C.-C.K. and T.M.B.; writing-original draft preparation, T.M.B.; writing-review and editing, C.-H.W. and C.-C.K.; supervision, C.-C.K. All authors have read and agreed to the published version of the manuscript.

Funding: This research received no external funding.

Institutional Review Board Statement: Not applicable.

Informed Consent Statement: Not applicable.

Data Availability Statement: The freely available data can be accessed through the indicated references whereas the remaining parts can be obtained from the corresponding author upon the reasonable request.

Acknowledgments: Supports for this research from Ministry of Science and Technology of the Republic of China, and Bahir Dar Energy Center are gratefully acknowledged.

Conflicts of Interest: The authors declare no conflict of interest.

\section{References}

1. Patel, A.; Singal, S.K. Off Grid Rural Electrification Using Integrated Renewable Energy System. In Proceedings of the 2016 IEEE 7th Power India International Conference (PIICON), Bikaner, India, 25-27 November 2016; pp. 1-5. [CrossRef]

2. Kamalam, D.S. Transforming Our World: The 2030 Agenda for Sustainable Development. Pondicherry J. Nurs. 2017, 11, 42-49. [CrossRef]

3. IEA (International Energy Agency). World Energy Outlook. 2019. Available online: https://www.iea.org/reports/world-energyoutlook-2019 (accessed on 16 July 2021).

4. Khan, R.; Schulz, N. Cost Optimization of Hybrid Islanded Microgrid for Rural Electrification. In Proceedings of the 2019 IEEE Power \& Energy Society General Meeting (PESGM), Atlanta, GA, USA, 4-8 August 2019; pp. 1-5. [CrossRef]

5. Içen, H.; Tatoğlu, F.Y. The Asymmetric Effects of Changes in Price and Income on Renewable and Nonrenewable Energy. Renew. Energy 2021, 178, 144-152. [CrossRef]

6. Nasir, M.; Zaffar, N.A.; Khan, H. Analysis on central and distributed architectures of solar powered DC microgrids. In Proceedings of the 2016 Clemson University Power Systems Conference (PSC), Clemson, SC, USA, 8-11 March 2016; pp. 1-6. [CrossRef]

7. Bukari, D.; Kemausuor, F.; Quansah, D.A.; Adaramola, M.S. Towards accelerating the deployment of decentralised renewable energy mini-grids in Ghana: Review and analysis of barriers. Renew. Sustain. Energy Rev. 2021, 135, 110408. [CrossRef]

8. IEA (International Energy Agency). World Energy Outlook 2018: Highlights; International Energy Agency: Paris, France, 2018; Volume 1, pp. 1-661.

9. Aboagye, B.; Gyamfi, S.; Ofosu, E.A.; Djordjevic, S. Status of renewable energy resources for electricity supply in Ghana. Sci. Afr. 2021, 11, e00660. [CrossRef]

10. Government of Ghana. Ghana Renewable Energy Master Plan. Accra. 2019. Available online: http://www.energycom.gov.gh/ files / Renewable-Energy-Masterplan-February-2019.pdf (accessed on 5 January 2021).

11. Emad, D.; El-Hameed, M.A.; Yousef, M.T.; El-Fergany, A.A. Computational Methods for Optimal Planning of Hybrid Renewable Microgrids: A Comprehensive Review and Challenges. Arch. Comput. Methods Eng. 2020, 27, 1297-1319. [CrossRef]

12. Suman, G.K.; Guerrero, J.M.; Roy, O.P. Optimisation of solar/wind/bio-generator/diesel/battery based microgrids for rural areas: A PSO-GWO approach. Sustain. Cities Soc. 2021, 67, 102723. [CrossRef]

13. Ko, W.; Kim, M.-K. Operation Strategy for Maximizing Revenue of an Energy Storage System with a Photovoltaic Power Plant Considering the Incentive for Forecast Accuracy in South Korea. IEEE Access 2021, 9, 71184-71193. [CrossRef]

14. Jani, A.; Karimi, H.; Jadid, S. Hybrid energy management for islanded networked microgrids considering battery energy storage and wasted energy. J. Energy Storage 2021, 40, 102700. [CrossRef]

15. Bahramara, S.; Moghaddam, M.P.; Haghifam, M. Optimal planning of hybrid renewable energy systems using HOMER: A review. Renew. Sustain. Energy Rev. 2016, 62, 609-620. [CrossRef]

16. Rana, M.; Romlie, M.F.; Abdullah, M.F.; Uddin, M.; Sarkar, R. A novel peak load shaving algorithm for isolated microgrid using hybrid PV-BESS system. Energy 2021, 234, 121157. [CrossRef] 
17. Hafez, A.; Abdelaziz, A.; Hendy, M.; Ali, A. Optimal sizing of off-line microgrid via hybrid multi-objective simulated annealing particle swarm optimizer. Comput. Electr. Eng. 2021, 94, 107294. [CrossRef]

18. Oladigbolu, J.O.; Ramli, M.A.M.; Al-Turki, Y.A. Feasibility Study and Comparative Analysis of Hybrid Renewable Power System for off-Grid Rural Electrification in a Typical Remote Village Located in Nigeria. IEEE Access 2020, 8, 171643-171663. [CrossRef]

19. Odou, O.D.T.; Bhandari, R.; Adamou, R. Hybrid off-grid renewable power system for sustainable rural electrification in Benin. Renew. Energy 2020, 145, 1266-1279. [CrossRef]

20. Yuan, C.; Illindala, M.; Khalsa, A.S. Co-Optimization Scheme for Distributed Energy Resource Planning in Community Microgrids. IEEE Trans. Sustain. Energy 2017, 8, 1351-1360. [CrossRef]

21. Gebrehiwot, K.; Mondal, A.H.; Ringler, C.; Gebremeskel, A.G. Optimization and cost-benefit assessment of hybrid power systems for off-grid rural electrification in Ethiopia. Energy 2019, 177, 234-246. [CrossRef]

22. Das, B.K.; Hasan, M.; Rashid, F. Optimal sizing of a grid-independent PV/diesel/pump-hydro hybrid system: A case study in Bangladesh. Sustain. Energy Technol. Assess. 2021, 44, 100997. [CrossRef]

23. Shrestha, A.; Bishwokarma, R.; Chapagain, A.; Banjara, S.; Aryal, S.; Mali, B.; Thapa, R.; Bista, D.; Hayes, B.P.; Papadakis, A.; et al Peer-to-Peer Energy Trading in Micro/Mini-Grids for Local Energy Communities: A Review and Case Study of Nepal. IEEE Access 2019, 7, 131911-131928. [CrossRef]

24. Javed, M.S.; Ma, T.; Jurasz, J.; Mikulik, J. A hybrid method for scenario-based techno-economic-environmental analysis of off-grid renewable energy systems. Renew. Sustain. Energy Rev. 2021, 139, 110725. [CrossRef]

25. Ministry of Water, Irrigation and Energy of Ethiopia. Draft National Energy Policy (March 2021). 26 March 2021. Available online: http:/ / mowie.gov.et/- / raft-national-energy-policy-march-202-1?inheritRedirect=true (accessed on 6 April 2021).

26. Remy, T.; Chattopadhyay, D. Promoting better economics, renewables and $\mathrm{CO}_{2}$ reduction through trade: A case study for the Eastern Africa Power Pool. Energy Sustain. Dev. 2020, 57, 81-97. [CrossRef]

27. African Development Bank. Green Mini Grid Market Development Programme: Mozambique. Côte d'Ivoire. April 2017. Available online: https://www.aler-renovaveis.org/contents/lerpublication/afdb_2017_abr_mini-grid-market-opportunityassessment-mozambique.pdf: (accessed on 5 January 2021).

28. Garcia, M.M.; Hawes, S. Africa Energy Outlook 2019. France. Available online: https://www.iea.org/reports/africa-energyoutlook-2019 (accessed on 5 January 2021).

29. Park, E.; Kwon, S.J. Solutions for optimizing renewable power generation systems at Kyung-Hee University's Global Campus, South Korea. Renew. Sustain. Energy Rev. 2016, 58, 439-449. [CrossRef]

30. Gizachew, A.; Andargie, G. Challenges and prospects of lake Tana island monasteries as a tourist site since 1950s: The case of Kebran Gabriel. Afr. J. Hist. Cult. 2014, 6, 45-52. [CrossRef]

31. Bires, Z.; Raj, S. Determinants of environmental conservation in Lake Tana Biosphere Reserve, Ethiopia. Heliyon 2019 , 5, e01997. [CrossRef] [PubMed]

32. Li, J.; Liu, P.; Li, Z. Optimal design and techno-economic analysis of off-grid hybrid renewable energy system for remote rural electrification: A case study of Southwest China. Chem. Eng. Trans. 2020, 81, 115-120.

33. Azerefegn, T.M.; Bhandari, R.; Ramayya, A.V. Techno-economic analysis of grid-integrated PV/wind systems for electricity reliability enhancement in Ethiopian industrial park. Sustain. Cities Soc. 2020, 53, 101915. [CrossRef]

34. HOMER Energy. 2017. Available online: https://www.homerenergy.com/products/pro/docs/3.11/index.html (accessed on 5 January 2021).

35. Kolhe, M.; Ranaweera, K.M.I.; Gunawardana, A.G.B.S. Techno-economic analysis of off-grid hybrid renewable energy system for Sri Lanka. In Proceedings of the 7th International Conference on Information and Automation for Sustainability, Colombo, Sri Lanka, 22-24 December 2014; pp. 1-5. [CrossRef]

36. Rohani, G.; Nour, M. Techno-economical analysis of stand-alone hybrid renewable power system for Ras Musherib in United Arab Emirates. Energy 2014, 64, 828-841. [CrossRef]

37. Thomas, D.; Deblecker, O.; Ioakimidis, C.S. Optimal design and techno-economic analysis of an autonomous small isolated microgrid aiming at high RES penetration. Energy 2016, 116, 364-379. [CrossRef]

38. Features, K.E.Y.; Certificates, P. Canadian Solar Super Power CS6K-MS Data Sheet. Can. Sol. (USA). 2017. Available online: https:/ / www.solarelectricsupply.com/canadian-solar-cs6k-295mssolar-panel-wholesale-price (accessed on 26 January 2021).

39. Yimen, N.; Hamandjoda, O.; Meva'a, L.; Ndzana, B.; Nganhou, A.J. Analyzing of a Photovoltaic/Wind/Biogas/Pumped Hydro Off-Grid Hybrid System for Rural Electrification in Sub-Saharan Africa-Case Study of Djoundé in Northern Cameroon. Energies 2018, 11, 2644. [CrossRef]

40. Ucar, A.; Balo, F. Evaluation of wind energy potential and electricity generation at six locations in Turkey. Appl. Energy 2009, 86, 1864-1872. [CrossRef]

41. Adaramola, M.S.; Agelin-Chaab, M.; Paul, S.S. Assessment of wind power generation along the coast of Ghana. Energy Convers. Manag. 2014, 77, 61-69. [CrossRef]

42. Dhundhara, S.; Verma, Y.P.; Williams, A. Techno-economic analysis of the lithium-ion and lead-acid battery in microgrid systems. Energy Convers. Manag. 2018, 177, 122-142. [CrossRef]

43. Khan, M.R.B.; Jidin, R.; Pasupuleti, J.; Shaaya, S.A. Optimal combination of solar, wind, micro-hydro and diesel systems based on actual seasonal load profiles for a resort island in the South China Sea. Energy 2015, 82, 80-97. [CrossRef] 
44. Fioriti, D.; Lutzemberger, G.; Poli, D.; Duenas-Martinez, P.; Micangeli, A. Coupling economic multi-objective optimization and multiple design options: A business-oriented approach to size an off-grid hybrid microgrid. Int. J. Electr. Power Energy Syst. 2021, 127, 106686. [CrossRef]

45. Razmjoo, A.; Kaigutha, L.G.; Rad, M.V.; Marzband, M.; Davarpanah, A.; Denai, M. A Technical analysis investigating energy sustainability utilizing reliable renewable energy sources to reduce $\mathrm{CO}_{2}$ emissions in a high potential area. Renew. Energy 2021, 164, 46-57. [CrossRef]

46. Murray, S.; Deichmann, U.; Wheeler, D.; Meisner, C. The Economics of Renewable Energy Expansion in Rural Sub-Saharan Africa. In Productivity and Firm Exit during the COVID-19 Crisis: Cross-Country Evidence; World Bank: Washington, DC, USA, 2010; Volume 39, pp. 215-227. [CrossRef]

47. Authority, E.E.U. Energy Tariff Amendment Study According to Consumers Class Service Charge Rates for Four Years, Starting 2018 GC. Tariff 2018, 2-3. Available online: http://www.eeu.gov.et/images/The\%20new\%20tariff\%20adjustment\%202.pdf (accessed on 21 January 2021).

48. National Bank of Ethiopia. Macroeconomic and Social Indicators; Report; National Bank of Ethiopia: Addis Ababa, Ethiopia, 2020; Volume 1, pp. 2000-2002. 